\title{
N. F. S. GRUNDTVIGS BREVE TIL HANS HUSTRU UNDER ENGLANDSREJSEN 1843
}

Af Jørgen Fabricius.

Medens Grundtvigs breve til hustruen fra de tre første englandsrejser blev udgivet $\mathrm{i} 1920^{1}$ ) af børnebørnene, har almindeligt kendskab hidtil været savnet til tilsvarende breve, skrevet under den fjerde og sidste englandsrejse, fra hvilken tidligere kun er offentliggjort ialt 10 breve fra Grundtvig, hvoraf 7 breve er til dronning Caroline Amalie $^{2}$ ), 2 breve til sønnen Johan ${ }^{3}$ ), og 1 brev til sønnen Svenn ${ }^{4}$ ). I direktør, cand. polit. Ingolf Boisens ${ }^{5}$ ) arkiv findes imidlertid Grundtvigs 11 breve til hustruen fra denne rejse, og takket være direktør Boisens interesse og velvilje fremlægges nu disse breve, som ikke alene på flere punkter supplerer kendskabet til Grundtvigs personlige oplevelser og umiddelbare indtryk under rejsen, men også giver værdifulde træk til billedet af Grundtvig som ægtemand og familiefar.

En af de sidste dage i april (måske allerførst i maj) 1843 bad dronning Caroline Amalie ${ }^{6}$ ) Grundtvig skrive »et lille Vers der udtrykte de smaae Børns inderlige Tak til den kjærlige Konge og Landsfader«, som torsdag den 4. maj ville følge sin gemalinde til hendes asyl ${ }^{7}$ ) for at bese de nye lokaler, som »vi skylder hans Godhed«. Grundtvig skrev da sangen: »Dejlig springer Skoven ud, alle Fugle sjunge $\left.\ll^{8}\right)$ og var efter dronningens indbydelse selv til stede ved kongebesøget $\mathrm{i}$ asylet. - Den følgende dag sendte dronningen Grundtvig følgende brev $^{9}$ ):

\section{Herr Pastor Grundvig!}

Det var et længe næret, inderligt Ønske hos mig, at være istand til at bidrage til en Opmuntrings og Adspredelses Reise for Dem, til Engeland! Vor kjære Herre har taget Sig af dette Ønske, og ved 
den kjærlige Konges Godhed for mig, er jeg nu sat istand til at opfylde det. Der vil desuden aabnes Dem en Credit i Engeland hvorom jeg nærmere skal underrette Dem saa at De paa ingen Maade skal komme til at være i nogen Forlegenhed. Men nu Spørgsmaalet om De ogsaa virkelig har lyst til at reise? I Grunden tvivler jeg ingenlunde herom og vil blot bede Gud at denne Reise maae blive Dem til Glæde, os til Gavn!

Med inderlig Hengivenhed!

Caroline Amalie.

\section{Den 5. Mai}

1843.

Tydeligt nok har dronningen straks efter mødet mellem kongen og Grundtvig benyttet det gunstige indtryk, dette må have haft på majestæten, til at opnå en bevilling, som kunne sætte Grundtvig i stand til endnu en gang at besøge England, og efter en forudgående brevveksling ${ }^{10}$ ) er Grundtvig allerede den 10. maj dronningens gæst ved en middag på Sorgenfri slot for bl. a. at drøfte de »nærmere Bestemmelser angående Afreisen til Engeland $\kappa^{11}$ ). Her har Grundtvig utvivlsomt også redegjort for de mål, han har sat sig for rejsen, og hvorom han endnu dagen efter at have modtaget dronningens tilbud skriver til Gunni Busck ${ }^{12}$ ): »Saa skal jeg da, rimeligviis, for Alvor støde sammen med de halve og hele Papister i Oxford, og det nytter ikke at dølge for sig selv, der vil findes haarde Halse og uomskaarne Hjerter, saa Møien er vis og Virkningen meget tvivlsom, Gud give i Jesu Navn baade Viisdom og Taalmodighed!

Imidlertid staaer denne Reise ingenlunde sørgelig for mig, og naar jeg kun kan bevare den Sagtmodighed, der bør findes, hvor jeg ikke optræder som Missionær, men som Forsvarer af Mortens og vor Deel baade i den Catholske Kirke og Vorherre Jesus, da tør jeg nok haabe at meddele de Godtfolk i det mindste lidt bedre Forstand paa Kirkehistorien og deres eget Løsen »qvod ubique, semper et ab omnibus«, maaskee ogsaa at give den indbrydende Tydskhed et Rap, og den folkelige Retning et Skub, thi hvor der ikke er noget i Veien, vil Puseyiterne ganske anderledes forstaae mig end Folk heromkring«.

Selvom Grundtvig her fraskriver sig titlen »Missionær ( $^{13}$ ), er det tydeligt, at han begiver sig til England og nærmere bestemt til Oxford $i$ håb om at kunne yde en »indgribende Virksomhed $\kappa^{14}$ ) overfor den udvikling henimod hierarki og katolicisme, som han ser er sat i gang af oxforder-bevægelsen, hvis opståen og vækst Grundtvig mere indgående og interesseret end nogen anden herhjemme havde fulgt ${ }^{15}$ ). 
I løbet af maj måned har Grundtvig gennemført forberedelserne til rejsen $^{16}$ ) og herunder også vekslet breve med sin engelske ven Nugent $\mathrm{Wade}^{17}$ ), som beredvilligt påtager sig at tilrettelægge besøget i England, som han ikke blot med glæde ser hen til, men anser »of the greatest importance to the cause at large and most welltimed $\kappa^{18}$ ). Så snart pinsen (d. 4. og 5. juni) er forbi ${ }^{19}$ ), er Grundtvig da også parat til at tiltræde rejsen, vel vidende, at han, for at få det rette udbytte af denne, må være i Oxford, inden ferietiden begynder.

1.

Kiære Lise!

Lübeck Torsdag ${ }^{20}$ )

Lykkelig og vel ankom vi her omtrent Kl. 1. uden anden Modgang end Vindens og Strømmens, som Dampen overvandt. Gaden her fandt vi vel spærret, fordi det høie Raad sad i dybe Tanker og kunde ikke taale Vogn-Rummelen, men Fodgængere var det dog tilladt at træde sagte paa de toppede Stene, og jeg vil haabe, det var ingen Krigs-Erklæring imod Danmark ${ }^{21}$ ) den gamle Hansestads Borgermester og Raad sad og pønsede paa. - Paa Dampskibet var kun et lille Selskab men udvalgt, foruden din Mand og $\mathrm{S}^{22}$ ), General Qvade $^{23}$ ), Oberstl. Lønborg ${ }^{24}$ ) og Daglig-Dags-Hovedmanden ${ }^{25}$ ). Vil Gud, afgaae vi imorgen tidlig til Hamborg ${ }^{26}$ ) og opholde os saalænge i »de fem Taarne«, dog ikke i det gamle Huus der har dem $^{27}$ ). - Opvarteren paa Dampskibet bringer dig nok dette og en Epistel fra Svenn, jeg [ved] ikke til hvem ${ }^{28}$ ), da Du sagtens længes efter at høre om vort første Skridt, skiøndt det kun var kort og ei meget mærkeligt - Møens Klint saae vi kun i Tusmørke.

Hils nu alle gode Venner og især Børnene ${ }^{29}$ ) og Jan ${ }^{30}$ ), og vær kun ubekymret for os! Med Guds Hjelp gaaer Alting godt!

i Hast

Din

Frederik.

[Udskrift på brevet:]

Fru Grundtvig

Hjørnet af Vimmelskaft og Knabro-

stræde Nr. 134 A. 2den Sal.

Kjøbenhavn. 
2.

Kiære Lise!

London 13de Iuni 1843

Gud skee Lov, at jeg kan skrive herfra og sige, at baade Svenn og jeg befinder os vel, men dette maa næsten ogsaa blive Alt hvad $\mathrm{Du}$ faaer idag, thi Frue Browne ${ }^{31}$ ) skulde gaaet iaften og taget Brev med, men $\mathrm{da}^{32}$ ) for det daarlige Veir hun opsætter Reisen, maa jeg hos hendes Syster, Lady Radstock ${ }^{33}$ ), i en Hast skrive et Par Linier, som endnu giennem det udenlandske Departement kan komme med Posten og sige Dig, hvad jeg veed $\mathrm{Du}$ og vore Kiære særdeles længes // efter at høre. Reisen var noget urolig fra Hamborg ${ }^{34}$ ) hertil, Svenn laae for det meste i Køien, men havde det for Resten ret godt, og igaar Middags $\mathrm{Kl} .12 \mathrm{kom}$ vi op til $\mathrm{Mr}$. Wades, som ligefra Morgenstunden havde været ude for at møde os, men ikke truffet Øieblikket, men baade Han og Dennis ${ }^{35}$ ) kom snart hjem og modtog os paa det Kiærligste. To Værelser har vi faaet tæt ved Præsteboligen og vor lille Stadsestue har ganske fortryllet Svenn.

$\mathrm{Nu}$ maa Du nøies med dette til Fru Browne reiser med næste Dampskib og bringer Dig vist et langt Brev fra os // Begge. Hils kiærligst hele Huset og da især vore Børn, som jeg vil haabe giør Alt for ikke at lade deres Moder føle noget Savn,

Kys dem fra Din

Frederik.

[Udskrift på brevet:]

Fru L. Grundtvig

Vimmelskaftet 134

Kiøbenhavn

3.

London 16de Jun 1843

(27. Bunhill Row Finsbury

London)

Kiære Lise!

Iaften bliver det da nok Alvor med Fru Brownes Reise, og skiøndt jeg haaber, Du allerede paa Søndag eller Mandag vil faae det Par Linier hvormed jeg meldte dig vor Ankomst til London, vil jeg dog her gientage det, at vi lykkelig og vel ankom i Mandags ved virkelig Middagstid, efter en meget urolig Søndag, som jeg ligetil henimod Aften tilbragde i Køien ${ }^{38}$ ). Paa Toldboden slap vi, efter endeel Ophold, skikkelig igiennem, undtagen med min stakkels Smule Tobak, som de annammede og beholdt, thi vel tilbød de mig det igien, naar 
jeg betalde $15 s h(7 r d l)$ i Told, men det syndes mig for galt, skiøndt jeg sagtens, naar jeg skal kiøbe Tobak kommer til at betale i samme Forhold og faaer det slettere. Tobakspiben har imidlertid alt saagodtsom faaet Afsked, da jeg ikke nænner at bedrøve Mistress Wade og knap nok at ryge en enkelt Pibe her i vort pæne Sidde-Værelse (sitting-room).

At vi nemlig, som jeg ønskede har faaet 2 pæne Værelser tæt ved Mr. Wades Bolig i et stille Huus vil Svenn, som finder sig særdeles vel ved Sopha, Lænestol, Tæpper og alt saadant Herskabeligt, ventelig med Fornøielse beskrive.

Min Mave har, ventelig især for det Londonske Vand, som jeg har drukket endeel af, gjort et // lille Oprør, som kommer noget ubetimelig og nøder mig til ubehagelig Stilhed, men, med Guds Hjelp, vil det vel nu være overstaaet, saa vi, efter vort Bestik, kan gaae [til] Oxf ord paa Mandag. Om Svenn gaaer med, veed jeg endnu ikke, da han maaskee vil finde det for haardt at skilles fra Dennis, og jeg, i Følge med Mstr. Wade jo nok kan undvære ham nogle Dage. Han sidder nu, tænker jeg, første Gang ordenlig fast i det Brittiske Museum, hvor jeg forleden Dag indførde ham ${ }^{37}$ ), og da Dennis har Examen i hele denne Tid, fristes han ikke til at drive hele Dagen. Mistress Wade var paa Landet, hos sin Moder, da vi kom, men er nu vendt tilbage, og kappes med sin Mand i venlig Omhyggelighed for os, saa jeg er kun lidt forlegen med, hvordan jeg skal erstatte dem de Omkostninger, de giør for os hver Dag med alle vore Maaltider.

Jeg har ellers endnu ingensteds været undtagen hos Mistress Brownes Syster, Lady Radstock, hos hvem jeg to Gange har mødt Fru Browne, spiist Mellemmad Kl. 2, og ført Samtale med hende, en meget dannet Dame af den store Verden, som giver os Breve med til Professor $\mathrm{Pusey}^{38}$ ) og Flere i Oxford. Der saae jeg ogsaa igaar Fru Brownes ugifte Syster, som skal være lidt sær, men hele denne Familie kommer mig, for Fru Brownes Skyld, // imøde med al muelig Venskabelighed.

Jeg var forleden Dag, med Mr. Wade første Gang i mit Liv, tilstæde i Overhuse ${ }^{38}$ ), hvor jeg hørde Hertugen af $W_{\text {ellington }}{ }^{40}$ ), den udenlandske Minister, Jarlen af Aberdeen $^{41}$ ), Brougham ${ }^{42}$ ) og andre fornemme Talere, blandt hvilke dog Ingen, uden Brougham særdeles udmærkede sig. - Regn har vi havt en god Deel af, men igaar og idag deiligt Solskin. - Mine Briller glemde jeg, saa det er Noget af det Første, jeg maa see at anskaffe mig i London.

Mærkværdigt nok var vi paa Dampskibet mellem 19 Passageger 8 Danske og deriblandt en rig Planter fra Jamaica, som, efter 40 Aars 
Fraværelse havde besøgt sin gamle Fader i Jylland og bragde ham nu med sig 88 Aar gl. for at vise ham Engeland. Denne gamle Skoleholder ${ }^{43}$ ) som aldrig havde været udenfor Jylland og kunde ikke et engelsk Ord, men var rask og rørig, blev ikke lidet glad ved i mig at finde en Landsmand, som kunde snakke med ham om Folk og Steder i Jylland, men han blev snart søsyg og troede da næsten, hans Liv havde Ende. Dersom vi gaar til Nord-Engeland, seer jeg ham maaskee engang endnu, da Sønnen har givet mig sin Adresse og boer omtrent paa den Vei.

Mr. Wade boer lige ved Siden af sin Kirke, og jeg var igaar morges tilstæde ved Morgenbønnen, som der bestandig holdes, og var vel // kun lidt besøgt, men meget opbyggelig.

$\mathrm{Nu}$, kiære Lise! maa jeg slutte for denne Gang, da jeg endnu har et Brev til Dronningen at giøre færdig ${ }^{44}$ ), og er just ikke i min fulde Kraft. Gud velsigne og bevare Dig med Børnene og hele Huset og alle gode Venner! Johan gaaer nok hen og hilser Bojsenerne $e^{45}$ ) fra $\mathrm{mig}$, som da igien vil hilse Th. Fenger ${ }^{46}$ ) venligst, eller Du seer maaskee selv Nogen af dem en af Dagene. Svenn siger, at I har bestemt faaet vor Adrese, men for en Sikkerheds Skyld har jeg dog sat en kortere over Brevet, som vil være tilstrækkelig.

Kan jeg faae Tid, vil jeg skrive et Par Ord baade til Johan og Meta $^{47}$ ), men hvis ikke, da hils dem fra en Fader, som tænker idelig paa sine Børn og ønsker intet saa inderlig paa Jorden som at kunne ret egenlig omfavne dem i Kiærlighed og omgaaes dem med uindskrænket Fortroelighed. - Gud give os det i Vorherres Jesu Navn!

$\mathrm{Nu}$ kære Lise! længes jeg efter at høre, hvordan I har det, og hvad Du har betænkt for Sommeren. Det er jo omtrent nu Busck vil komme til $\mathrm{Vebæk}^{48}$ ), hils ham paa det Kiærligste! Ogsaa ham skrev jeg naturligviis gierne til ved denne gode Leilighed, naar jeg kunne overkomme det. - Hils nu Jane og alle Systerne ${ }^{48}$ ) med deres Huse kiærlig! G 1 a $\mathrm{h}^{50}$ ) vil jeg haabe, er nu rask igien. - Mr. Wade hilser venligst ved

Din egen

Frederik

[Udskrift på kuvert:]

Fru Elise Grundtvig

Vimmelskaftet 134

Kiøbenhavn 
4.

Kiære Lise!

Oxford 25de Juni

(Søndag) ${ }^{51}$ )

S ve n n sendte mig igaar Dit og Metas $B_{r e v}{ }^{52}$ ), thi han er i London hos Dennis og jeg har været med Mr. Wade her i Oxford hele Ugen siden i Mandags, da vi foer herned, det meste af Veien paa Jernbanen, som slet ikke behagede mig. Mit første Brev fra London kunde Du ikke have før i Søndags eller Mandags, men det baade kunde og vilde blevet meget længere, naar det ikke var gaaet skævt. Mit andet Brev, med Fru B r o w n e tænker jeg, Du har faaet i Torsdags, og vil deraf have seet, at jeg befandt mig kun maadelig den første Uge i Engeland, saa jeg maatte have baade Doctor og Medicin, men den Anden, her i Oxford, har, Gud ske Lov! været desbedre, og vi har havt alt det Held med os, der vel lod sig vente, thi at Engelskmændene i det Hele er underlig stive Personer, vidste vi jo forud og maatte regne paa. Vi boer meget godt $i$ et gammeldags Conditori ${ }^{53}$ ) hos en gammel snaksom Madame, og har hidtil næsten hver Dag spiist frit $\mathrm{i}$ »D r o n n ing e n s Collegium ${ }^{54}$ ), hvor vi var anbefalede til en Mr. Barrow ${ }^{55}$ ), // der i alle Maader har behandlet os som gamle Venner og Bekiendter, og i Selskab med ham og en anden ung Præst, Mr. Daman ${ }^{56}$ ) gjorde vi alt i Torsdags en meget behagelig Fodtur til en Landsby i Nærheden, ved Navn Sandford, hvor Præstens Moder, Kone og Sydskende mødte os tilvogns og holdt Frokost. Da vi havde spiist, blev alle Børnene fra Gaden kaldt ind og fortærede de ikke ringe Levninger baade af Mad og Viin, som Oxforderne havde bragt med sig, og det var mig ordenlig rørende at see, paa saa smuk en Maade gik det Hele for sig. - Da de var bange for, jeg skulde have gaaet over Evne, maatte jeg kiøre hjem med de ældre Damer og de Unge gik.

Paa denne Tour kom vi ogsaa til en anden Landsby Litlemore, hvor En af Hovedmændene for de nye Anglikanere Mr. Newman ${ }^{57}$ ) har indrettet sig et Slags Kloster og lever der med nogle yngre Mænd og mange Bøger. Jeg snakkede vel med ham en af de følgende Dage i Oriels-Collegiet ${ }^{58}$ ), hvoraf han er en Medlem, men Samtalen var meget fattig, skiøndt det af hans Bøger er klart, at han ogsaa indvendig er // hvad man kalder en rig Mand. Idag har jeg hørt ham præke, og jeg har aldrig hørt Nogen, der havde Noget at sige tale saa sagte, men just derfor var der ogsaa en overordenlig Stilhed udbredt over hele Kirken, saa jeg hørde, om ikke hvert Ord, saa dog i det Hele meget godt. Langt var det vist nok fra, at jeg kunde underskrive Alt hvad han sagde, men dog var der et Alvor og en Dybde 
i det Hele, som lod mig beklage, at han slet ingen Lyst synes at have til at høre Andre end sig selv.

Dr. Pusey, efter hvem man har kaldt hele Partiet Puseyiter har Feber og kan derfor ikke taale megen Tale, men dog har han meget venlig modtaget mig to Gange, og bedt mig komme en vis Tid paa Dagen, saa tit jeg vil, og det er Alt hvad jeg kunde forlange.

Med min Pibe er det reent Fjas -

London 30te Juni (Fredag)

Her sidder jeg da igien i Stilhed, thi skiøndt midt i London, maa jeg kalde dette Stilhed i Sammenligning med Oxford, hvor man vel ikke hører stort til Rummel eller Maskiner, men hvor jeg og min Mund var i bestandig Bevægelse. Det er endnu // halvveis som en Drøm for mig, med alle de nye Bekiendtskaber jeg har gjort og alle de Samtaler, jeg har ført i Hjertet af Englands aandelige Liv, og de sidste Dage var især rige paa mærkværdige og stærke Sammenstød. Mr. Newman gjorde mig i Mandags et Besøg og midt under en meget varm Samtale med ham traadte en Mr. Waldegrave $^{58}$ ) af det modsatte Parti ind i Stuen, hvorpaa Mr. Newman strax stod op og gik, og siden har jeg hverken seet ham eller Dr. Pusey, som jeg ved mit næste Besøg fandt bortreist, saa de har kun været lidt fornøiede med mig.

Mr. Waldegrave er ogsaa en Præst af fornem Herkomst, til hvem Lady Radstock havde anbefalet os, men han syndes reent at have glemt os, og da han nu i Mandags faldt med Dørren ind i Huset og forstyrrede min Samtale med Mr. Newman, kan du neppe forestillig dig, hvor grov jeg var imod ham, saa da han indbød os til Middag $\mathrm{i}$ hans Collegium til Onsdag, sagde jeg ham reent ud, at jeg var ikke kommet [til] Oxford for Mad og Drikke, og da han en hel $\mathrm{Uge}^{60}$ ) havde ladt os skütte os selv, havde jeg nu ingen Lyst til at være hans Giæst. Jeg mærkede // vel hvor forbauset Mr. Wade blev over min mageløse Grovhed, men jeg ærgrede mig saameget over, at han nu tilsidst vilde have Skin af Forbindtlighed, at jeg besvarede alle hans Undskyldninger med en Landtur, Embedsforretninger etc. med den tørre Anmærkning, at »to Linier《 vilde han altid havt $t^{61}$ ) Leilighed til at sende mig. D et slog ham tilsidst, han tilstod, han burde have skrevet mig til og bad om Forladelse, og nu var naturligviis det ubehagelige Optrin forbi, thi saa snart jeg saae, han i alt Fald fortrød sin fornemme Skiødesløshed, lovede jeg naturligviis at komme, og bad ham undskylde ethvert haardt Ord, som jeg kun havde brugt under den Forudsætning at 
han ikke brød sig om os men vilde blot til sidst som en F o r m a lit t e t besøge og indbyde os. I Onsdags var vi da hans Giæster tilligemed to af hans Venner, hvoraf den Ene, Mr. Lytton ${ }^{62}$ ), er en Hovedmand blandt Anti-Puseyiterne, og her forefaldt den skarpeste Tvist, jeg har havt i Oxford, og vel en af de skarpeste i mit Liv, som kun afbrødes med Mr. Lyttons Bortgang, som skulde holde en Eftermiddags-Prædiken. Samtalen fortsattes imidlertid uden Tvist ligetil det blev mørkt, og vi maatte afbryde, da vi havde lovet os ud om Aftenen, og denne Samtale var uden tvivl en af de frugtbareste, jeg nogensinde har ført, thi Mr. Waldegraves anden Ven Mr. Goulburne ${ }^{83}$ ) havde følt sig saa slaaet af den Maade hvorpaa jeg forfægtede det 》levende Guds-Ord $\kappa^{64}$ ) og Gienfødelsens Bad i D a ab e n, med Mr. Lytton, at han higede efter al mulig Oplysning i denne Livets og Salighedens Sag. - Det Mærkværdigste // var dog endnu, at igaar, da vi stod færdig at forlade Oxford, traadte Mr. Waldegrave ind ad Dørren med - Mr. Lytton, for at fortsætte Samtalen og overtale os til at forlænge vort Ophold i Oxford. - Det Sidste skedte nu vel ikke, men dog glemde jeg under Indpakningen i Hurlumhei, mine Tøfler og lovede omtrent at komme tilbage til Oxford mellem 20de og 27de Juli. - Svenn var i Torsdags kommet ned til Oxford ${ }^{65}$ ) og skiøndt det for en Dagstid var vel megen Udgift, fornøiede det ham dog saameget at see det store Muse-Tempel og høre en Opførelse af 》Skotske Sange《 at jeg ikke vil fortryde det. Om vor Reise nordop er endnu Intet bestemt, men skal vi til Oxford igen om 3 Uger, som jeg ved Eftertanke finder nødvendigt, kan den vel først finde Sted i August. Hvordan Mellemtiden vil gaae, veed kun Gud, men jeg haaber, den vil ikke heller være frugtesløs. Lady Radstock maa jeg besøge og hun vil da uden tvivl efter Løfte, føre mig ind $\mathbf{i}$ sin Kreds, hvor det ventelig især bliver D a m e r $\mathbf{n}$ e, jeg skal have med at giøre. Hun nævnede saaledes især en Hertuginde ${ }^{68}$ ), hvis Navn jeg har glemt, som en gudfrygtig Dame af den mest bestemte Carachter, med hvem hun vilde giøre mig bekiendt. - Jeg var i Onsdags tilstæde ved en Universitets-Fest i Oxford, hvorom man i Danmark ei kan giøre sig mindste Begreb. - Festen holdes $\mathrm{i}$ en stor Sal, hvor Gulvet optages af alle M a gistre ne og deres Venner. Siderne som gaae amphitheatralsk i Veiret er besat med lutter Damer $\mathrm{i}$ fuld Stads og $\mathrm{i}$ hundredeviis og tæt under dem, paa en Forhøining sidder Vice-Cantsleren ${ }^{67}$ ), Universitetets andre Embedsmænd og nycreerede Doctores, medens // Galleriet er fyldt med Studenter, som paa denne Dag har deres Frisprog, kan klappe eller ${ }^{88}$ ) pibe af hvem de vil, men denne Gang blev det til et helt Oprør, saa efterat Galleriet havde givet sine Følelser Luft en- 
stund som sædvanlig, og Stadsen skulde begynde med en Latinsk Tale, Oplæsning af Pris-Afhandlinger etc., blev Galleriet ved at raabe og støie saa umaadelig, at man ikke kunde høre Ørenlyd, alle Cantslerens Forsøg paa at stille Bulderet var frugtesløse, og da endelig den Latinske Tale, som det ene Nødvendige, var oplæst (til $\mathrm{m}$ it store Morskab) aldeles $\mathrm{u} h ø \mathrm{rt}$, maatte Festen afbrydes, hvad aldrig før skal være oplevet, og var et Hjertestød til alle de Studenter, som havde vundet Prisen, og havde tildels faaet deres Systre og hele Familie op for at høre deres Berømmelse. Hos En af disse Mr. Barry bivaanede vi saaledes en stor og kostbar »Mellemmad Kl. 1-2《 hvor jeg havde hans Syster tilbords, og da hun havde Munden til Tjeneste, blev jeg indviet i den hele Hemmelighed, og holdt til Giengixld en lille offentlig Forelæsning ${ }^{68}$ ) overborde for at bevise Damerne at siden de var de ypperste Tilhørere ved Festen burde de vænne Universitetet af med at $\mathrm{snakke} L$ atin, en Materie, hvori Du nok veed, jeg er uudtømmelig paa Dansk og selv paa Engelsk saa veltalende, at Engelskmændene, som aldrig har hørt et saadant Kiætteri af en gammel Latiner høilig forundre sig.

Dog, det nytter ikke, at jeg vil beskrive Dig mit Trojanske Tog til Oxford, der er alt for rigt paa Begivenheder, til at jeg engang kan huske dem alle, og da Græcismen i mig ei kan rose sig af nogen Seier, der afgiør det mindste, fortjener Toget heller intet Epos. To af mine barbariske Forelæsninger ${ }^{70}$ ) // den Ene i Dronningens Collegium mellem Vinflaskerne om Forholdet mellem Rom og Grækenland, Tydskland og Engeland og en Anden ved Thebordet hos Mr. Daman over Nordens Mythologi, er tilligemed mine idelige Udraab om den Angel-Sachsiske Kirkes og Literaturs store Betydning hvad der i Oxford syndes at giøre mest Opsigt, og da Ugen 20-27 Juli i Anledning af et Jubilæum vil midt under Ferierne blive meget livlig, haaber jeg da $\mathrm{i}$ alle Maader at kunne fortsætte min Kamp mod alt $\mathrm{Uh}$ is torisk og for Norden med Engeland, under lykkelige Varsler.

1ste Juli

Mens vi idag sad ved Middagsbordet, fik Mstr. Wade ondt, og nu, en Time efter, er hun allerede Moder til en ny Datter, den Tredie, som med to Sønner udgiør en skikkelig Børneflok i hendes 26de Aar. - Jeg vilde naturligviis $\mathrm{i}$ denne Tid nødig giøre Uleilighed, men Mr. Wade vil intet høre om, hvad jeg under disse Omstændigheder ønskede, at tage Maden hvor vi bor. Jeg vandrede næsten hele Formiddagen med Svenn for at finde Dr. Bowring ${ }^{71}$ ), men da vi omsider 
fandt hans Huus i den anden Byende, var han ikke hjemme, saa den Gang var hardtad forgiæves, dog afgav jeg mit Kort med Bopæl, saa, hvis han ikke er blevet alt for fornem, høre vi vel fra ham.

\section{4de Juni ${ }^{72}$ ) (Tirsdag)}

Endnu har vi Intet hørt fra jer siden I saae Brev fra London. Imorges frokostede vi hos Dr. Bowring, som er blevet en fornem Mand, men ligner sig dog selv som en godmodig Vindmager. Da han reent har slaaet sig fra Literaturen, kan vi for Resten neppe have megen Gavn af ham. Nu venter vi med Længsel ${ }^{73}$ ) paa gode Tidender fra alle vore Kiære, og hvad vi ikke kan skrive, vil Dennis fortælle jer om vor Lyksalighed i London ${ }^{74}$ ).

Hils nu kiærligst Børnene, Jane og alle gode Venner, og vær selv først og sidst hilset som mindet af din Frederik.

\section{[Udskrift på kuvert:] \\ Fru Elise Grundtvig \\ Kiøbenhavn ${ }^{75}$ )}

5.

Kiære Lise

London 10de Juli 43

Tak for dit Brev, sluttet 30te Juni, som ankom 7de Juli i Fredags, og i denne Henseende vil jeg bemærke, at naar I skriver om $\mathrm{M}$ a ndag en (da Ch. 8 gaaer) vil vi ogsaa have det om Fredagen, og hver 8de Dag venter jeg Brev fra Hjemmet, Postpengene er her i Forhold til andre Udgifter ingen Ting. At $\mathrm{Du}$ virkelig, som $\mathrm{Du}$ skriver, er rask igien, vil jeg haabe, jeg er Gud ske Lov! ved god Helbred. Du er tvivlraadig om din Reise, vel egenlig fordi Du havde mest Lyst til at giæste Falster $^{78}$ ), men jeg maa gientage hvad jeg sagde, det maa vel synes en urimelig Frygt jeg har for en saadan Reise, men jeg har den ligefuldt, saa jeg kan umuelig ønske den.

Af Nyt har jeg denne Gang kun lidt at fortælle, thi Tiden gaaer jævnt med at vandre til og fra det Brittiske Museum $^{77}$ ) og en Boglade $^{78}$ ), som endnu er // længere borte. Lady Radstock har saa travelt med sine egne Morskaber, at hun knap i forrige Uge kunde finde een Time tilovers, og det skulde været i Fredags, men siden udsatte hun det til Løverdag, da vi fik Skylregn, saa jeg blev hjemme. Derved fik jeg imidlertid en Visit af vor Minister (Grev Reventlow) hos hvem jeg saa spiste til Middag i Aftes Kl. 7 og traf hans Broder 
med to Systre fra Lolland ${ }^{78}$ ). De var Alle meget forbindtlige, og da Greven selv tilbød mig at modtage mine Breve til Hjemmet, faaer Du vel dette fra det udenlandske Departement. Da de hørde, jeg havde min Søn med, sagde Grevinden strax, at han skulde ogsaa med den næste Gang, men $\mathrm{n}$ a a $\mathrm{r}$ det bliver, veed jeg ikke. Af nye Bekiendtskaber har jeg nylig ingen gjort uden med Erkebispen fra Dublin $^{80}$ ), som jeg egenlig blev indført til hen i Veiret og frokostede med i Fredags en Dansk Mil her fra kun til lidt Fornøielse paa /I begge Sider.

Svenn og jeg var forleden Dag paa en $\mathrm{C}$ h i n e s is k Udstilling ${ }^{81}$ ) egen i sit Slags. I et Huus bygget paa Chinesisk finder man nemlig baade Chinesiske Guder og Mennesker eftergjorte, og omringede af af Chinesiske Meubler, Handelsvare, Værktøi, Bøger etc., saa man faaer et anskueligt Billede af hele Chineseriet, der vel ikke er tiltrækkende, men dog ret mærkværdigt, og hvad der især tildrog sig min Opmærksomhed var Malerier af Havnen ved Canton og andre Chinesiske Egne, der ret lod mig see en vildfremmed Verden.

Jeg husker ikke, om jeg sidst fortalde dig, at vi havde frokostet hos Dr. Bowring, men i alt Fald vil jeg dog her bemærke, at han er blevet en heel Diplomat, som næppe havde Stunder til at tale et Par Ord // med os, men kun til, efter lang Venten blandt hans Fruentimmre med megen Vigtighed at vise os om i en radical $\mathrm{Klub}^{82}$ ), udstyret med en Pragt, som jeg troer selv Keiseren af Rusland vilde misunde Londons Demokrater. Fruen inviterede os til en stor $\mathrm{Fa}$ milie Fest paa Løverdag Aften Kl. 9, men jeg benytter mig neppe deraf.

Mstrs. Wade har vi vel ikke seet endnu, men hun befinder sig dog ret vel, og selv Barselsenge kan jeg mærke, tages langt anderledes let $i$ London end i Kiøbenhavn. -

$\mathrm{Nu}$, kiære Lise! farvel for denne Gang! hils Børnene, Jane, Systrene og alle gode Venner, som Du seer, paa det Kiærligste! Svenn skriver til Meta og vil da selv hilse og fortælle baade hvor flittig han besøger Museet, og hvor vel han befinder sig i den store Stad. Gud velsigne og bevare os paa begge Sider!

Din

egen Frederik

[Udskrift på kuvert:]

Fru E. C. M. Grundtvig,

Hjørnet af Vimmelskaft og

Knabrostræde. 134. A.

Kjøbenhavn. 
6.

Kiære Lise!

Sidste Uge hørde vi slet Intet fra Danmark men idag haaber jeg da endelig at see Brev, og høre baade at I er raske og hvor I nu opholder jer. Fru Fenwich, Mstr. Wades Svigermoder, reiser i Aften med to Døttre til Danmark og har lovet at besørge dette Brev til Vimmelskaftet, hvor det sagtens ikke træffer jer, men dog Anstalt for Modtagelse og Afsendelse. - Paa Mandag skulde vi nu, i Selskab med Mr. Wade, tiltræde Reisen til Oxford, Nord-England og Edingburg, skiøndt jeg for min Part heller blev i Syden enstund og reiste saa hjem, især da Nord-Reisen efter al Rimelighed vil koste langt mere end den er værd i mine Øine. Da Mr. Wade imidlertid har Mod paa Reisen og Mr. Svenn endnu mere, følger jeg forsaavidt Strømmen, og vil haabe baade at Omkostningerne blive i Forhold taalelige og at Nytten tør blive større end jeg kan forudse. Livet her har siden sidst været temmelig mechanisk, som det Meste i London, saa Dagen er gaaet med Frokost, en Vandring til Museet eller til en Boghandler i Vestenden, Middagsmad, Kik i en Bog og Thevand til Sengetid, et Levnetsløb jeg naturligviis ei skulde ønske at fortsætte ret længe, men forsaavidt det lykkes mig at // see mærkelige Mænd og erhverve eller læse vigtige Bøger, som kun findes her, kan jeg en stund ret godt finde mig deri. - I Aftes var vi alle Tre i Underhuset $^{83}$ ), men jeg fik snart min Fornøielse, da jeg næsten slet ikke kunde høre, og det desuden kun var maadelige Talere der kom paa Benene, medens Resten sad og holdt Snak. - Forleden Dag frokostede jeg hos En af de navnkundige Tory-Medlemmer: Sir Robert Inglis ${ }^{84}$ ), en godmodig og sagtens rig Baronet, men som ikke har opfundet Krudtet. Mr. Wade og jeg spiste forrige Fredag til Middag hos Lord Radstock, men næsten ganske alene, saa det var først til Thevand jeg saae endeel nye Ansigter, mest Damer af Familien, og det Hele var at betragte som en Høflighed af Fru Brownes Syster. Reisen til Richmond i forrige Uge, hvor vi besøgte Fru Fenwich, blev narret med Omnibussen og maatte traske hjem et Par Danske Miil tildels i Skylregn, beskrev jeg vel sidst, men det Bedste, at jeg, Gud ske Lov! slap godt derfra, kan jeg først melde nu. - Mrs. Wade har nu (efter 3 Ugers Forløb) aldeles overstaaet sin Barselseng og idag skal Barnet i Kirke ${ }^{85}$ ), før Fru Fenwich gaaer ombord. - Jeg vil haabe $\mathrm{D}$ e $\mathrm{n} \mathrm{n}$ is bragde dig Hilsenen fra os, skiøndt han intet taler om det $i$ et Undskyldnings-Brev ${ }^{88}$ ), jeg havde fra ham fordi han glemde Brevene hernede i // Gangen, skiøndt han indbildte sig, de med hans Pult var stjaalet fra ham paa Dampskibet. 
Hvordan det nu vil gaae med vore Breve, mens vi er paa Reise, veed jeg ikke ret, men fra Edingburg skriver jeg naturligviis og naar Du adresserer dine Breve til Mr. Wades (St. Paul's Finsbury. Parsonage house) faaer jeg dem nok, om end lidt senere. At jeg begynder at kiedes lidt ved den store Stad og ønsker mig hjemme i min gamle Stue og mellem mine Kiære, seer $\mathrm{Du}$ nok af dette lidt kiedelige Brev, men det vil ikke undre Dig, da Alderen i alle Maader giøre os tungere baade at flytte, og til at dreie os mellem fremmede Folk og Forhold $^{87}$ ), saa hvis jeg blev her længe, blev jeg vist gnaven. - Igaar har jeg forlist et af mine Silke-Lommetørklæder, men, paa Handsken nær, som jeg altid mister, er det dog nok ogsaa det første Forliis denne Gang, og naar det ogsaa maa blive det Sidste, har jeg intet at klage. Med den sorte Kuffert blev vi skammelig narrede, det var kun P a pi r med et tyndt Overtræk, saa jeg maa kiøbe en ny til Reisen.

Justitsraad Thomse $\mathrm{n}^{88}$ ) traf jeg endelig forleden Dag i Medaile-Cabinettet, men det bliver vel ogsaa Alt. - Forleden Aften drak en Nordmand ${ }^{80}$ ) The her, som gaaer til Syd-Afrika paa Missjon, og det var mærkeligt nok, at skiøndt vi var 7 Personer foruden ham, kunde han dog paa sin Norsk forstaaes af os alle og hørde baade Dansk og Norsk Sang af Miss. Fenwicherne. /I

$\mathrm{Nu}$, kiære Lise! Gud befalet! jeg vil haabe, I er alle raske og at Landturen ${ }^{80}$ ) vederkvæger jer, saa vi kan samles glade i Septbr., thi naar vi kommer tilbage nordfra, agter jeg at giøre Opholdet her saa kort som mueligt, hvad sagtens Kassen ogsaa vil tilraade. -

Hils nu kiærligst Johan, Meta og hvem der ellers er dig nær, og, faaer Du Brevet i Bjergby, da hils Busck tillige, at jeg har tænkt oftere paa at skrive ham til men vidste hverken hvor jeg skulde begynde eller ende, saa der bliver ventelig intet af, og i alt Fald, vil en lang Samtale ene kunne besvare de mange Spørgsmaal, han har til mig, men hvad $\mathrm{Du}$ veed, vil $\mathrm{Du}$ lade ham vide.

Jeg skrev sidst J oh a n til igien, og han har sagtens ei været bedre fornøiet med det andet $\mathrm{Brev}^{01}$ ) end med det Første, men det faaer ikke at hjelpe, jeg kan ikke længer udholde det fremmede Væsen imellem os, netop fordi jeg elsker ham faderlig, og jeg haaber dog med Guds Hjelp, vi maae komme paa den fortrolige Fod, som hans Alder svarer til, og hans Fremtid kræver. - Siig Du ham dog ogsaa, at han jo nok kan begribe, jeg ikke vilde sige ham et ubehageligt Ord med Overlæg, naar jeg ikke fandt det nødvendigt, og at det er alt for urimeligt, naar en Søn tager sin Fader det ilde op. Jeg venter nu Brev fra Meta, og da skal hun ogsaa faae et til! 


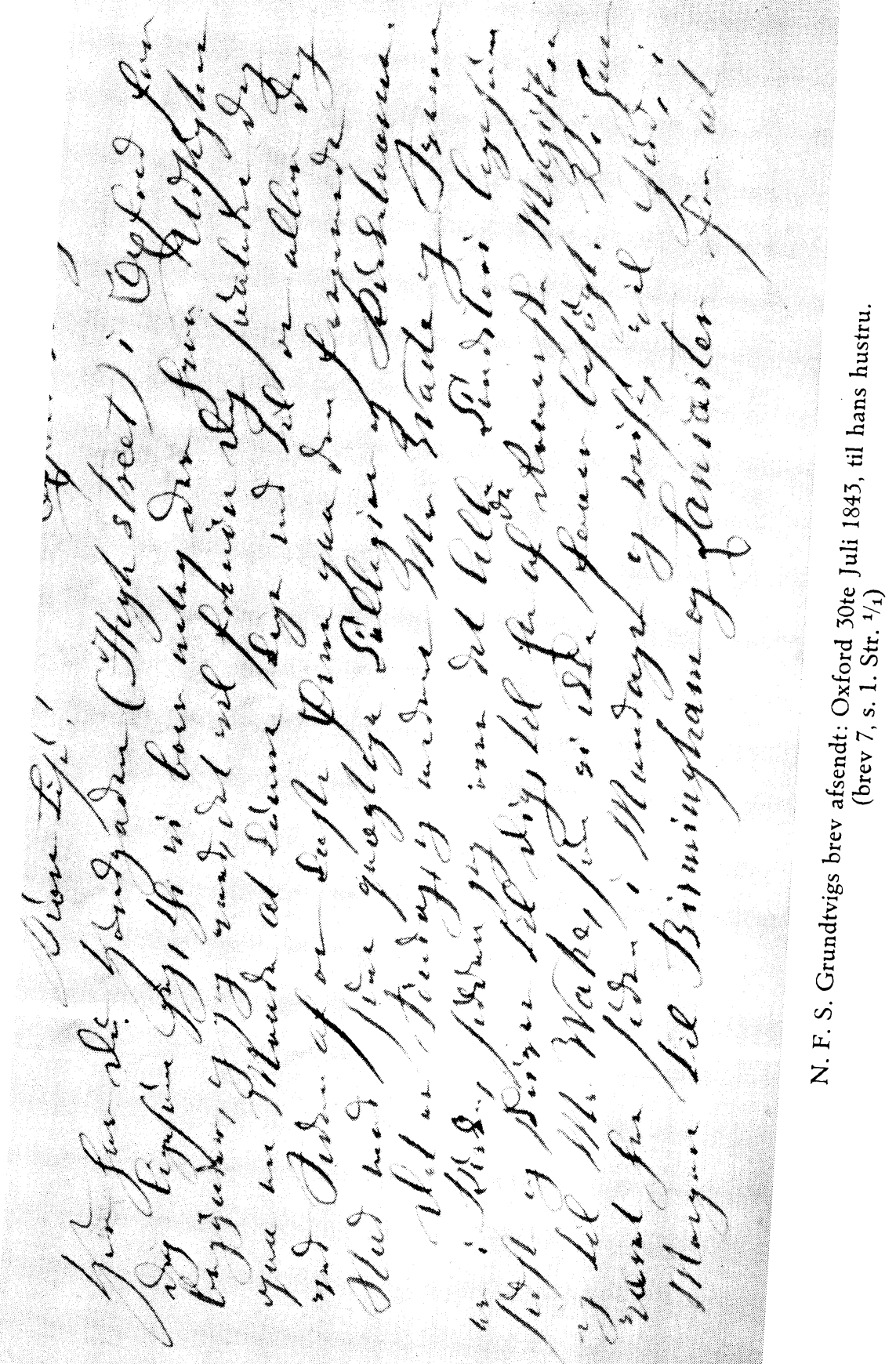





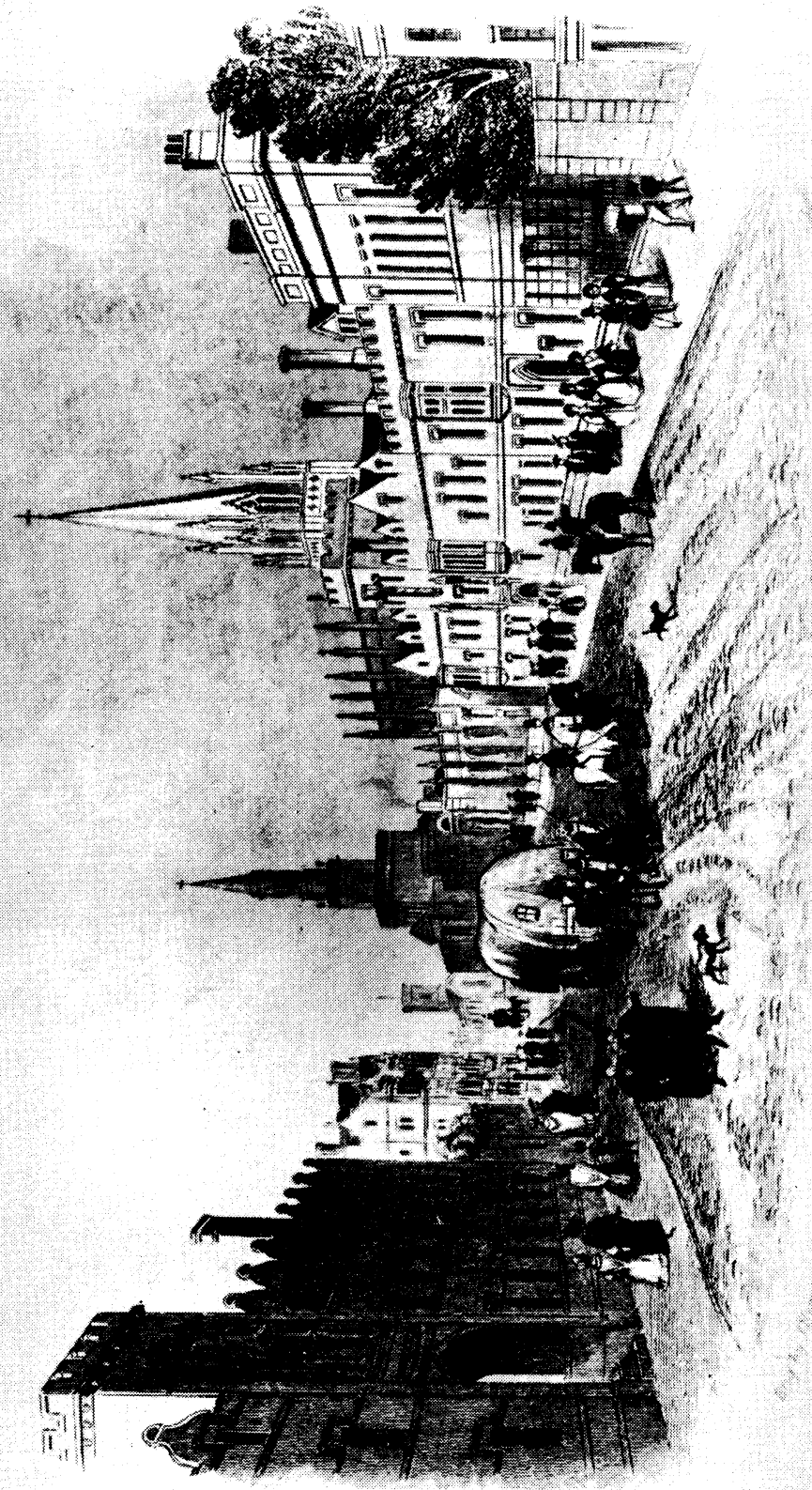


Rum til to Linier vil jeg spare i Haab om høiere op paa Dagen at see Brev fra min egen Kone, og henlever i alt Fald Din Frederik

Jeg var lidt urolig, da det blev Aften før jeg fik dit kiære Brev af $15 \mathrm{de}$, men det kom, da vi sad tilbords og jeg har nu just Tid til at takke dig og ønske jer alle Guds Fred og glade Dage! Sedlerne har slet ikke fordyret Brevene, tak Meta for $\sin ^{92}$, men hun har i $\mathrm{n} \mathrm{u}$

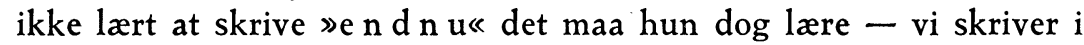
alt Fald fra Edingburg inden maaske fra Kendal.

\footnotetext{
[Udskrift på kuvert:] ${ }^{93}$ )

Fru Elise Grundtvig

add: Pastor Busck

Stiftsbjerby

per Holbek
}

\section{Kiære Lise!}

7.

Her har Du Hovedgaden (High street ${ }^{95}$ ) i Oxford for dig ligesom jeg, thi vi boer netop der hvor Udsigten begynder, og jeg veed, det vil fornøie dig saaledes dog paa en Maade at kunne kige ind til os eller dog ved Siden af os kaste Øine paa den fremmede Stad med sine prægtige Collegier og Kirketaarne.

Det er Søndag, og medens Mr. Wade og Svenn er i Kirke, sidder jeg over det lille Conditori ligesom sidst og skriver til dig, til En af $\mathrm{de}^{98}$ ) Romerske Magistre ${ }^{97}$ ) og til Mr. Wake ${ }^{98}$ ), som vi ikke faaer besøgt. Vi har været her siden i Mandags og reise, vil Gud, i Morgen til Birmingham og Lancaster for at // see Cumberlands berømte Søer og vor gode Ven Mr. Barrow, som har hjemme der. Vort Ophold i Oxford denne Gang har vel været meget stillere end sidst, da jeg hverken har seet Pusey eller Newman, og de fleste Fellows er borte, men dog har vi været temmelig optagne til Frokost og Middag i »Alle Sjæles« Collegium ${ }^{99}$ ) hos Mr. Waldegrawe, og i Magdalene-Collegiet $^{100}$ ), som ligger tæt ved os og hvor Mr. Wade og jeg endnu i Dag skal spise til Middag hos Præsidenten Dr. Routh ${ }^{101}$ ), en Olding paa 88 endnu baade rørig og livlig. Svenn har flittig besøgt det B o d l e i a n s k e Bibliothek ${ }^{102}$ ), hvortil det ikke lidt bidrog at Bibliothekaren Dr. Bandine ${ }^{103}$ ) strax tog sig faderlig af ham, gav ham sit eget lille Rum at arbeide $i$ og behandlede ham i det Hele som en lille Prinds, for hvem Alt maatte staae paa Pinde, saa han havde Lykken med sig ligesom da han skulde $\mathrm{g}$ a a e til Roskilde ${ }^{104}$ ). I Gaar Eftermiddags gik han og jeg til den nærmeste Skov for dog at have 
været $\mathrm{i}$ en Engelsk Skov, og hvor vi laae et Par Minuter, var vi enige om, at efter Alt hvad vi der saae, kunde vi ligesaa godt været midt i Sælland, som mellem Oxford og London, saa hjemligt saae alting ud. Vi besaae ellers ogsaa i Gaar to Collegier, som vi slet ikke havde seet før nemlig 》Trinity ${ }^{105}$ ) og Merton $\aleph^{106}$ ). I det første fandt vi imidlertid intet at beundre, uden at det skulde være $S ø l v t ø i$ et, men i »Merton« som er det ældste af alle Collegierne (fra det 13de Aarhundrede) fandt vi et Slags Vaabenhuus, der hos os kunde giælde for en skikkelig $\mathrm{Kirke}^{107}$ ), og inden for en deilig Kirke med malede Vinduer, og fandt et Bibliothek ${ }^{108}$ ) // saa raat, at nogle gamle Folianter endnu hængde i store Jernlænker ved Hylden.

Hvem jeg denne Gang har talt mest med, er unge Magistre, som er næsten rene Papister, og deriblandt en $\mathrm{Mr}$. Palmer $^{108}$ ), som nylig er kommet hjem fra Sverrig og havde saa tit hørt af de Svenske Præster, at det var »Grundtvigske" Ideer han kom med, at han var glad ved at finde mig her; men naturligviis kunde vi ikke enes, da vi vel tale meget ligt om »K i r k e n« men han taler om den, som om den kun bestod af $B$ is per $\mathrm{n}$ e og hvem de vil lukke ind, istedetfor at jeg veed den, med og uden Bisper, bestaaer af alle dem »som troe og er døbte«, troe hvad vi vil alle ved Daaben bekiende og er døbte derpaa til Samfund med Faderen og Sønnen i den Hellig-Aand. Det er stor Skade, at saamange dygtige og dristige unge Mænd skal være hildede i den gamle papistiske eller hierarchiske Snare, men det er dog godt, at Kirke-Sagen ogsaa her igien er kommet alvorlig paa Tale, og Saameget haaber jeg, med Guds Hjelp, at udrette her, at i det mindste de Unge skal lære, man kan troe paa en hellig, almindelig Kirke uden at have det mindste enten med Paven eller alle $\mathrm{h}$ a $\mathrm{n} \mathrm{s}$ Helgene, hans Skiærsild og Rosenkrandse at giøre.

Hvad Bøger angaaer, da finder jeg her saa mange baade gamle og nye, som jeg ønskede at see og bruge i Kiøbenhavn, at, hvis jeg havde Rum og Penge dertil, vilde jeg komme hjem med et heelt Bibliothek. /I

Reisen til Skotland har jeg egenlig slet ingen Forestilling om, saa jeg ønskede igrunden helst, den var gjort allerede, men derfor kan den godt blive saa frugtbar, at jeg bagefter ingenlunde vilde undværet den, og mit næste Brev vil ventelig være dateret fra Glasgow eller Edingburg.

$\mathrm{Da}$ vi, mod Formodning, intet Brev fik sidste Uge, veed vi slet ikke, h vor vi skal tænke, I er, men dog formoder jeg jer i Dag i Lyngby hos den kiære Busck og ønsker, I maae have ligesaa smukt et Solskinsveir, som jeg ud af det halvaabne Vindue seer, det er i Oxford. Du maa endelig skrive engang om Ugen, at der dog ikke 
skal være længere end nødvendigt mellem Efterretningerne fra vore Kiære. Hils dem nu Alle fra os ved Leilighed, og da især J o ha n og $\mathrm{M}$ e $\mathrm{t}$ a, som jeg altid tænker mig ved Moders Side og vilde være urolig ved at tænke mig andensteds. Jeg lever i denne Tid saameget med $\mathrm{S} v \mathrm{e} n \mathrm{n}$ at jeg ret længes efter ogsaa at leve mere med hans Sydskende end hidtil, thi mine Børn, vil jeg haabe, er mig dog igrunden alle lige nær, og det vilde dybt bedrøve mig at tænke anderledes!

Silke-Lommetørklædet kom igien, og mine glemte Tøfler forefandt jeg i Oxford, saa, efter Svenns Regning er Alt vel inden Borde.

Lev nu vel, kiære Kone! og tænk, at Guds Engle omringe og ledsage os paa begge Sider, thi det er, Gud skee Lov! sandt, de giøre det, og det er lifligt at komme det ihu?

Din

Frederik

[Udskrift på kuvert:]

S. T.

Fru Elisa Grundtvig

Hjornet af Vimmelskaft \& Kna-

brostræde. No 134. A.

Kjøbenhavn.

8.

Edinburg

Kiære Lise!

9de Aug. 1843

Saaledes naaede vi da i Lørdags Maalet for vor Reise, og vi agte allerede imorgen ${ }^{110}$ ) at begive os paa Hjemveien til London, thi Mr. Wade kom hertil med Rosen i Ansigtet, har maattet ligge hele Tiden under Doctors Haand $i$ et dyrt Værtshuus og længes da naturligviis efter Hjemmet. Jeg, som slet intet Mod har havt paa Skotlands Reisen, afbryder den ogsaa gierne, og har desuden havt en stærk Diarehe, som jeg vel haaber nu vil være forbi, men er dog ikke at troe.

Den Smule Svenn og jeg har kunnet giøre os bekiendt med Staden og Folk ${ }^{111}$ ) deri har imidlertid været meget fyldestgiørende // thi Edinburg er jo vist i mange Henseender den smukkeste af alle Europas Hovedstæder, og den eneste Mand, vi har været hos, Bibliothecaren Mr. Laing ${ }^{112}$ ), har modtaget os som gamle Bekiendter, viist os om allevegne og bedt os til Bords idag. Den gamle Dr. Chalmers ${ }^{113}$ ), som staaer i Spidsen for de Misfornøiede, der har forladt Statskirken har jeg ikke seet, men tænker dog idag at træffe, skiøndt det jo ikke bliver stort, vi kan faae talt sammen, har vel ogsaa ondt ved at forstaae hinanden. 
Vores Bjergreise i Vestmorland og Cumberland omkring til de deilige Indsøer har vel Svenn beskrevet dig $^{114}$ ), thi han var ganske fortryllet af de nye Gienstande og stolte Udsigter, men ogsaa jeg fandt den $\mathrm{i}$ det Hele fornøielig, skiøndt den idelige Regn var mig ubehagelig, og vi nok Alle der blev dygtig // forkiølede. Kan vi nu som jeg haaber, med Guds Hjelp, slippe godt og snart til London, da tænker jeg at kunne komme rigtig hjem tidlig i September, og nu, da jeg har hørt og seet og sagt omtrent hvad jeg kunde og ønskede, og har i alle Maader introduceret Svenn i Engeland, nu længes jeg naturligviis efter Huus og Hjem, Hustru og Børn, gode Venner og gamle Sysler, saa jo før jeg nu kan ende Reisen, deskiærere skal det være mig.

Det er nu paa tredie Uge, siden vi hørde fra jer og det er meget længe, igaar fik vi vel et Brev, der havde løbet rundt efter os mellem Bjergene og derfra til Glasgow, og vi tænkde vist, det havde været fra jer, men saa, det var fra $\mathrm{R} ø \mathrm{rda} \mathrm{m}^{115}$ ). Den feilslagne Forventning var nu vel ikke Brevet gunstig, men det fornøiede os dog meget, baade at han saa levende havde tænkt paa os, og at sættes ved ham levende /" midt ind i de danske Smaabegivenheder. Han vilde just skrive dig til for at mane dig til Mehrn, og da Svenn siger, Du helst vilde være vor Bryllupsdag hos ham, tænker jeg Manelsen kom ret tilpas. Faaer Du nu disse Linier i Mehrn selv eller i Omegnen, da hilser Du kiærligst og takker for Brevet, men anden Giengæld faaer han ikke, i det mindste før vi kommer til L o n d o n.

$\mathrm{Nu}$ Tak, min Kone! for al din Kiærlighed til mig i og før de 25 Aar ${ }^{116}$ ), og til Børnene fra de undfangedes og fødtes! Af Guds Godhed har vi dem og mistede Ingen af dem, Han gav os, og saa dem voxne og velskabte for vore Øine! Takke nu Børnene ogsaa Gud, som vi tør haabe, fordi Han gav dem kiærlige og christelige Forældre, da er vor Lykke sjelden og vor Sølvbryllupsdag høitidelig for os alle, skiøndt vi ikke paa den skulde være legemlig samlede! Kys Børnene paa mine Vegne og hils Vennerne hvor Du er og hvor Du kommer paa det Kiærligste

fra

Din Frederik

[Udskrift på kuvert:]

Til

Fru Grundtvig

Kobenhavn

Ved $M r$. Brownes Godhed ${ }^{117}$ ). 
Kiære Lise!

Her sidder jeg da, Gud ske Lov! igien i vort gamle Værelse ved Grønningen, og jeg er langt bedre fornøiet med Skotlands-Reisen endt, end jeg var med Forestillingen om den og Besværlighederne, der dels nødvendig, dels hvad man kalder tilfældigviis ledsagede den. Til Glasgov kom vi da slet ikke, og Edinburg forlod vi saasnart Doctoren vilde tillade $\mathrm{Mr}$. Wade at reise, og det var i T or s dag s. Dagene i Edinburg var naturligviis ikke blot færre ${ }^{118}$ ), men ogsaa mindre behagelige og frugtbare, end de under gunstigere Omstændigheder kunne været, men denne Hovedstads mageløse Beliggenhed paa en Klippe-Skrænt tæt ved Havet, og Mr. Laings Utrættelighed giør os dog Dagene uforglemmelige. I Onsdags i et deiligt Sommerveir spiste vi hos Mr. Laing tæt uden for Byen ${ }^{119}$ ) og da vi gik hjem Kl. 9 gjorde vi et Aftenbesøg hos Dr. Chalmers, en berømt gammel Mand, som staaer i Spidsen for en Trediedel af Skotlands Geistlighed, der i denne Tid har skildt sig fra Statskirken. Dette Aftenbesøg, det eneste, der vilde lykkes, staaer nu vel for mig som en besynderlig Drøm, men den levende, heftige Olding, der slet ikke kunde finde sig i mine kirkelige Begreber, men nødte mig dog til at bie og drikke et Glas Vin med sig og hans gamle, betænksomme og venlige Kone, der tilsidst kom ind, tog Deel i Samtalen og vilde endelig have os enige, er dog venlige Skikkelser, som altid vil svæve for mig. //

For at giøre hvad Mr. W. kunde taale (han havde ligget af Rosen i Ansigtet) gjorde vi i Torsdags kun en meget kort Reise fra Edinburg og opholdt os 24 Timer i en lille By »Melrose ${ }^{120}$ ), hvor der er en stor Ruin af et prægtigt Abbedi og i Nærheden Abbotsford Walter Scotts berømte Herresæde ${ }^{121}$ ), som vi besøgde og fandt omtrent som han døde fra det, med hans store Bibliothek, hans Vaabensal, Studerekammer og selv endel af hans Gangklæder, thi alt dette forevises Fremmede af et $^{122}$ ) gammelagtigt Fruentimmer, medens Herregaarden er ubeboet og Sir Walters eneste Søn er Officeer ved den Ostindiske Hær. I Fredags fortsatte vi Reisen for Alvor ad en tildeels meget besværlig Bjergvei og naaede først i Mørkningen Newcastle, der, omringet af Kulminer, saae ud som en uhyre Smede, skjult i Røg. Her blev vi ikke længer end nødvendig og tidlig paa vor Bryllupsdag foer jeg med Svenn til Durham, hvor vi havde Brev fra Mr. Laing til Bibliothecaren ${ }^{123}$ ) og skulde see nogle gamle Angelsachsiske Haandskrifter, men da vi ikke fandt ham ved Cathedralen og der just var Gudstjeneste, gik vi derind, og det var mig meget høitideligt i den gamle Storkirke og under en smuk Chorsang at løfte mine Tan- 
ker og Bønner til Ham, som har hjulpet og velsignet hidindtil og vil saa fremdeles. Mærkværdig traf det sig ogsaa, at da Mr. W. som var blevet nogle Timer længere i Newcastle hvor han havde Erinde, kom til os i Durham, bragde han mig dit kiære Brev fra Bjergby, saa jeg skulde paa vor Bryllupsdag have den Glæde at høre gode Tidender fra Hjemmet. Vi naaede med Jernbanen // i Darlington Kl. 3-4 og rullede paa den endnu 12-13 danske Mil til Leeds, hvor vi vilde holde Søndag, da vi havde Anbefaling til Præsten Dr. $H_{o o}{ }^{124}$ ), en berømt Leder paa den Oxfordske Side. Hos ham og i Kirken tilbragde vi da Søndagen ret taalelig og igaar rullede vi henved 50 Danske Mil snart over og snart under Jorden til Lo nd o n, hvorved vi vel havde den Skræk, at alt vort Tøi var glemt en Snees D. M. bag os, men Kl. 9, da jeg sad og savnede Sloprok og Tøfler, see, da kom alle vore Pakkenelliker som ved et Hexeri gallopperende til os med det næste Tog.

Her har Du da, kiære Lise, Registeret over vort Skotske Tog, som vi, vil Gud, snart kan nærmere tales ved om, thi nu veed jeg ikke her at have mere at giøre end at berede mig paa Hjemreisen, som jeg tænker paa at tiltræde først i næste Maaned. - Er Du kommet ned til Syd-Sælland ${ }^{125}$ ), kunde vi maaskee mødes der og følges ad til Kiøbenhavn, thi saa god en Leilighed til at see Vennerne der, faaer jeg vel neppe i Hast. Hvis Du derfor er der, naar Du faaer dette Brev, da bliv til Du hører nærmere fra mig, men skriv i alt Fald strax, saa jeg før min Afreise kan vide, hvor mine Kiæreste er med Guds $\mathrm{Hjelp}$ at finde! Jeg kan ikke noksom takke først Vorherre og dernæst Dronningen for denne Reise, som jeg haaber i alt Fald baade Svenn og jeg skal længe have godt af, men nu har jeg ogsaa faaet min Fornøielse og længes efter Hjemmet, saameget mere, som min Mave denne Gang slet ikke synes ret at kunne forliges med den engelske Luft og Levemaade, saa jeg mindes idelig om, at jeg dog nu igrunden kun passer til min gamle Kabørk og // mine igroede Vaner. Svenn troer jeg ogsaa dog begynder at længes lidt efter Danmark, skiøndt han har befundet sig særdeles vel, og ret gjort sig til gode med sin første Udenlandsreise, hvortil han da ogsaa har havt al muelig Grund, da han baade i Engeland og Skotland har snarere mødt formegen end for liden Opmærksomhed ${ }^{126}$ ) og er i den Alder, som naturlig stunder til Verden og ser den fra den gunstigste Side; han vil da ogsaa kunne more jer langt bedre end jeg med Fortællinger om det underlige Land og alle de Forvandlinger af Skueplads, vi i den korte Tid har oplevet.

Jeg hører af Svenn, at Johan vilde til Falster ${ }^{127}$ ), jeg vil da haabe, han lykkelig og vel er kommet tilbage til Dig, og at han tænker paa 
at tage sig noget Ordenligt for der baade kan nytte og fornøie ham; thi til det skeer, er jeg meget urolig for hans Fremtid.

Til Meta skriver jeg maaskee et Par Linier, men hils i alt Fald hende og J o h a n paa det Kiærligste fra en Fader, hvis store Glæde er hans Børns sande Lykke, men hvis Begreber om Lykke vist nok er vidt forskellige fra Verdens, saa de maa vælge mellem dens og mine, og fristes naturligviis til at foretrække de Manges Vidnesbyrd for den Enes, især paa en Tid med $\operatorname{den}^{128}$ ) forfærdelige Overtro at $\mathrm{M} æ \mathrm{n} \mathrm{g} d$ e $\mathrm{n}$ s (Majoritetens) Mening er altid den rette. Da jeg slutter af dit Brev, at J a n e er hos Dig, saa hils ogsaa hende kiærligst, og alle vore Venner ved Leilighed! Fra Bøjsen har jeg intet seet.

Mr. Wade synes nu ganske frisk og er idag i Richmond hos sin Kone, som intet har vidst om hans Sygdom, og ventede os først engang i næste Uge.

$\mathrm{Nu}$ kiærligst Levvel fra Din Frederik og, hvis Svenn ikke skriver idag, hans sønlige Hilsen!

[Udskrift på kuvert:]

Mrs. N. F. S. Grundtvig

to the care of $A$. Schmidt Esqr ${ }^{128}$ )

276. Nyhavn, Charl. Side.

Copenhagen

paid to Hamburg.

10.

Kiære Lise!

London 20de Aug. 1843.

(Søndag)

Svenn og jeg vilde været i den store St. Pauls ${ }^{130}$ ) til Højmesse idag, men vi kom nogle Minuter efter at Tjenesten var begyndt og maatte da lade os afspise med den Besked af en Politiknegt, at det var f o $r$ s i l d e. Ogsaa heri speiler sig Høikirkens Dødhed, thi hvor der er ${ }^{131}$ ) mindste Liv i den Følelse, at Kirken er til for Menneskets og det for Menneskets Saligheds Skyld, der kan man vel kalde en Kirkegang saavelsom Omvendelse seen, men, saalænge Ordet lyder, a ld rig f o $r$ seen, da man maa haabe det Bedste og maa vide, at det sidste Ord tit udretter langt mere end det Første.

Tak for dit Brev af 12te og 13de, hvoraf jeg seer at vi dog Begge fik Breve paa vor Bryllupsdag, og var de end begge lidt gamle, saa lignede de saameget bedre Egteparret, og mindede os om, at det aldrig nytter at ville kalde de bortflygtede Aar tilbage eller fremtvinge de udbrændte Følelser. Vi er $i$ alle Maader og til alle Tider 
langt under hvad vi skulde være, og ligesom vore Ungdoms-Følelser var langtfra at være saa rene, som de skulde, saaledes var det ogsaa Daarskab at vente // de paa Alderdommens Rand skulde have bevaret al den Friskhed og Fylde, som vi maatte ønske. Det gaaer vist nok hermed, som med al Rigdom og Fattigdom, at den Sidste synes sørgeligere end den Første, om end Rigdommens Feil og Farer er de største, men naar Gud dog har bevaret vore Hjerter, saa de banke kiærlig for hinanden og stræbe at have Alt tilfælles, da skal vi takke Ham for en Lykke, der slet ikke er hverdags og langt at foretrække sande om end fattige Udtryk for de glimrende men tomme og ei misunde Verden det Skin af Rigdom, den stræber ivrigst at give sig, naar den har mindre end Intet. Havde det været Guds Villie, at Sølvbryllupsdagen var oprundet for os $i$ en venlig Krog af Fædrenelandet, med vore Børn omkring os, og omtrent ene med dem, da er jeg vis paa, det vilde været en af de glædeligste i vort Liv; men nu var det anderledes, saa jeg skulde tilbringe den paa en engelsk Dagvogn ${ }^{132}$ ) og Jernbane kun med Svenn og Du i Pedersborg ventelig kun med Meta, siden $\mathrm{Du}$ ikke nævner Johan, nu er det intet Under, at lidt Beklemmelse mest udmærkede Dagen, og det skal trøste os at Guds Velsignelse og Hjertets Glæde er hverken bundet til Aar eller Dage, saa naar vi samles, kan og // vil Vorherre nok give os hvad vi kan bære, og desvissere, jo mere vi har vogtet os for at indbilde os $^{133}$ ) selv eller hinanden, at trods Adskillelsen og alle ugunstige Omstændigheder, var vore Følelser saa levende og sammensmeltende, som vi kunde ønske og som de vel vilde været for 25 Aar siden, hvis vi da havde befundet os i samme udvortes Omstændigheder.

Det glæder mig naturligviis hvad Du siger om Johans Betænkning, Gud lade den blive fast og frugtbar, thi hvad jeg ef te $\mathrm{r}$ de T reds daglig meer og næsten utaalmodig maa ønske, er at mine Sønner, efter deres Anlæg og Kræfter, maatte gaae ind i min Virksomhed til baade at lette mig dens Slutning og danne sig til en levende Fortsættelse deraf; thi naar de kun vil og kan forstaae det, da skal det vise sig, at ingen Fader mindre end jeg kan ønske at have sine Sønner til sine Skygger eller sit Echo, men ønsker inderlig, at de, som Modersmaalet herlig udtrykker sig, maae staae paa mine Skuldre og see videre, og naar jeg synker, have Mod og Kraft til at gaae videre og virke i den samme Aand med al den Forskiellighed, som Kræfter og Gaver, Tid og Omstændigheder giøre til Vilkaar for det Levende, Naturlige og Betimelige, der ene giør Virksomheden glædelig og frugtbar. En saadan Lykke er vist nok langt mere end jeg er værd, og nuomstunder en stor Sjeldenhed, da Ungdommen sædvanlig indbilder // sig, den kun i noget Splinternyt, aldeles Selv- 
stændigt kan finde Rum for en fri og fornøielig Bane; men da det er aandløst Daarskab, har jeg altid haabet og haaber fremdeles, at Gud vil skiænke mig den Glæde, som Han veed, betingede mit Ønske om Børn, før de fødtes, at deres Fædres Aand maae være over dem og Guds Rige deres Maal!

Efter dit Brev at slutte, er Du ikke kommet til Rørdam, saa ${ }^{134}$ ) vi kunne mødes i Syd-Sælland, men dit næste Brev vil maaske vise en Forandring, og, vil Pengene slaae til, finder jeg det endnu rimeligst $i$ September, som jeg ${ }^{135}$ ) saavidt raader for, at see til Vennerne i Sælland, som jeg ellers har vanskeligere ved at komme til.

Siden vi kom til London, gaar Dagene temmelig dødt, men da der dog er Adskilligt baade at faae seet og gjort, kan jeg ikke bekvemt vende Næsen hjem før om 14 Dage.

$\mathrm{Nu}$, kiære Lise! lev vel, ihvor $\mathrm{Du}$ er, og hils venligst omkring dig! Johan, vil jeg haabe, er kommet vel tilbage fra Falster, skiøndt det giøre mig lidt urolig, at han, efter eders Brev, ei synes at være kommet til den 12te, som Meta skrev, han vilde, og som var rimeligt nok.

Til Meta tænker jeg at skrive et Par Linier, og i alt Fald hilser Du hende fra os, at vi naturligviis ikke blot tænke paa men ogsaa tit tale om hende og alle vore Nærmeste! kiærligst Din Frederik

\footnotetext{
[Udskrift på kuvert:]

S. $T$.

Fru Elisa Grundtvig.

Addr. Hr. Grosserer A. Schmidt

Nyhavn, Charl. Side.

Nr. 276.

Copenhagen.

p. to Hamb.
}

11.

London

28de Aug. 1843

Kiære Lise!

At vi intet Brev fik i Fredags, gjorde mig vel lidt urolig, men imorges saae vi dog, Gud ske Lov! af eders Breve fra 22de og 23de Aug, at I lykkelig og vel var samlede i Hjemmet. Vi agte nu ogsaa, vil Gud, paa Løverdag at tiltræde Hjemreisen ${ }^{136}$ ), men da jeg slet ingen Underretning har kunnet faae om »Løven《 og Christian 8. ikke anløber noget Sted mellem Kiel og Kiøbenhavn, kan jeg herom 
kun sige, at d e r so m enten Løven eller noget andet Dampskib afgaaer fra Kiel Tirsdag, Onsdag eller Torsdag og anløber enten $\mathrm{Ka}$ llehauge eller Vordingborg, da agter jeg at gaae med det, men hvis ikke, da gaaer jeg lige til Kiøbenhavn.

*) Det er 5te, 6te eller 7de Sept. (Indlæggerens Anm.) ${ }^{137}$ ) //

Herom vil $\mathrm{Du}$ nu lettelig kunne skaffe dig Underretning og derefter tage din Bestemmelse, saa vi ikke, Gud for Alt, skal forfeile hinanden.

Vi har nu i disse Dage travelt, kan Du troe, da vi har opsat mange Ting til det Sidste og Svenn dog skulde have seet Londons HovedMærkværdigheder, saa han ordenlig til Vinter kan holde Forelæsninger for jer om den store Stad.

Jeg ved ikke om $\mathrm{Du}$ husker $\mathrm{H}$ e nde r s o ${ }^{138}$ ), som opholdt sig længe i Kiøbenhavn før vi blev gift; han havde just nu igien været der nogle Dage og hørt jeg var her og imorges ledte han ${ }^{139}$ ) mig op, men jeg kunde slet ikke kende ham igien. Han bestyrer ved et PræsteSeminarium udenfor London, hvor vi har lovet at spise hos ham i Morgen.

Overmorgen, om Veiret, som falder temmelig fugtigt, vil tillade det, skulde vi til Richmond // at sige Farvel til Mistress Wade, som opholder sig der, og see Slottet Hampton Court $t^{140}$ ) med det Samme.

Hils nu Systre, Svogre og alle vore Venner $\left.{ }^{141}\right)$, som Du seer, med Tak for Deres kiærlige Deltagelse, og hils da især Meta og Johan, med Tak for Deres Breve, som jeg i Aften ikke faaer Stunder at giengælde, men glemmer derfor ingenlunde, og haaber, de skal blive bedre fornøiede med deres Fader, naar han kommer selv end med hans Bogstaver, som altid er stive og kolde Personer. Vel skulde Meta kiende sin Fader bedre end at græde over, at han lastede hendes Skrift, men det, tænker jeg, hun vil selv lee ad, naar vi sees, og vel er det Johans egen Skyld, om jeg har miskiendt eller misforstaaet ham, da han længe har skjult sig for mig; // men langtfra at gaae videre i Rette med ham om det, vil jeg inderlig takke Gud, naar vi kun nu, som jeg haaber, lære bedre at kiende og forstaae hinanden, thi det er mit Hjertes inderlige Begiæring at leve paa den fortroligste Fod med mine voxne Børn, enige med dem i Grunden, og delende med Dem Alt hvad jeg har og veed, som er godt, uden at ville paatvinge dem Noget, de endnu ikke er modne til at modtage og levende anvende! Kun maa jeg sige dem, det er deres egen Skade, hvis de ikke, hvor de selv fattes tilstrækkelig Erfaring, vil troe deres Faders Vidnesbyrd, til de overbevises om, han tog feil, thi vil vi altid først blive kloge af Skade, maae vi betale svære Lærepenge. 
Lev nu vel, kiære Lise! og tvivl ikke paa, at Han, som er god og Hvis Miskundhed varer evindelig, vil velsigne og bevare os, naar vi stole paa Ham og forene os i sin Kiærlighed!

Din egen

Frederik.

\author{
[Udskrift på kuvert:] \\ Mrs. N. F. S. Grundtvig \\ Vimmelskaft, No 134. A. \\ Copenhagen. \\ paid to Hamborg.
}

\title{
NOTER OG HENVISNINGER
}

Ved udgivelsen er det tilstræbt at gengive brevene i så nær overensstemmelse med de foreliggende tekster som muligt, hvorfor enhver rettelse, også af åbenlys fejlskrivning, forkert tegnsætning og lign. er undgået, undtagen $i$ ganske enkelte tilfælde, hvor i [] er indsat det formodede manglende ord i en ellers ufuldkommen sætning. Hvor det ikke tydeligt fremgår, om et personligt pronomen er skrevet med »stort-D《 eller »lille-d《, er nugaldende retskrivningsregler fulgt. I et stort antal tilfælde har et skøn måttet afgøre, hvorvidt Gr. har ønsket at markere »punktum《 eller »tankestreg« eller begge disse tegn. Understregninger er markeret med $s p$ ati e $r$ et skrift og anvendelse af latinske bogstaver (specielt $\mathrm{i}$ engelske navne) med kursiv, medens afslutning på brevside angives ved //.

I nogle tilfælde har det beklageligt nok ikke været muligt med de til rådighed stående hjælpekilder (på Det kgl. Bibliotek, Rigsarkivet og Universitetsbiblioteket) at fremskaffe alle ønskelige biografiske data om alle personer, som omtales i brevene, omend identiteten i alle tilfalde er klarlagt. - Af pladshensyn er henvisninger undgået, hvor kilderne er almindelig kendte opslagsværker, og af samme hensyn er anvendt følgende forkortelser: Bibliografi (I-III) = Bibliografi over N. F. S. Grundtvigs Skrifter af Steen Johansen, I-III (Kbh. 1948-52). - Breve II = Breve fra og til N. F. S. Grundtvig II (1821-1872). Udgivne af Georg Christensen og Stener Grundtvig (Kbh. 1926). - Brun I = Biskop N. F. S. Grundtvigs Levnedsløb, udførligst fortalt fra 1839. Et Bidrag fra H. Brun, cand. theol. 1ste Bind (Kolding 1882). - Catalogue $=\gg$ A Catalogue of Books, purchased in Great Briten, 1843 by Gr.« Et dobbeltark (i D. F. S.) $(99 \times 159 \mathrm{~mm}$, præget med krone i øverste venstre hjørne på s. 1), på hvis tre første sider Gr. med latinsk skrift har anført ialt 63 bøger, som han har købt og på s. 4, 28 »Books presented to ditto.« Af listen, som også foreligger i en af Sv. Gr. systematisk opstillet renskrift (dog kun omfattende 53 stk. købte bøger), noteres her kun bøger, som er foræret Gr., eller skrevet af personer, som omtales i brevene. - Danskeren V = Danskeren, Tidsskrift for Land og By. Udgivet af Fr. Nygård og L. Schrøder, V Bind (Kolding 1891), s. 195-220: N. F. S. Grundtvigs Breve fra England til Dronning Karoline Amalie. 1843. Ved F. L. Grundtvig. - D. B. L. (I-XXVII) 
$=$ Dansk biografisk Leksikon (Kbh. 1933-44). - D.F.S = Dansk Folkemindesamling 1910-20 (Svenn Grundtvigs arkiv: Litterære notitser m. m.). D. N.B. (I-LXIII, 1. suppl. I-III og 2. supp. I-III) = Dictionary of National Biography (London 1885-1900, 1901 og 1912). - Fasc. (nummer) = Grundtvig arkivet fascikel (nummer). - Gad XXV = Gads Danske Magasin. Redigeret af Erik Rindom, 25de Aargang (Kbh. 1931), s. 312-23 og 403-16: Svend Grundtvig: Englandsbreve. Ved Ingeborg Simesen. - M. E. B. (I-VI) = Modern English Biography by Frederic Boase (Truro 1892-1901 og 190821). - N.k.S. = Ny kongelig Samling, 4, 3700. - Oxford $=$ A hand-book for visitors to Oxford (Oxford 1875). - Rejse-Dagbog $=\gg$ Rejse-Dagbog for Svenn Grundtvig. 1843« (i D. F. S.). Ulinieret notsbog $(100 \times 163 \mathrm{~mm})$ indeholdende Sv. Gr. korte daglige notater fra englandsrejsen. - Rønning IV, $1=$ N. F. S. Grundtvig. Et bidrag til skildring af dansk åndsliv i det 19. århundrede af Fr. Rønning. Fjerde bind - første del (Kbh. 1913).

1) N. F. S. Grundtvigs Breve til hans Hustru under Englandsrejserne 1829 -1831. Udgivne af deres Børnebørn (Kbh. 1920). - ${ }^{2}$ ) heraf 1 i Breve II og 6 i Danskeren V. $-{ }^{3}$ ) Breve II: nr. 477 og 478. - ${ }^{4}$ ) Gad XXV, s. 410. 5) Søn af Sognepræst Harald Imanuel Boisen (1857-1904) og hustru Ingeborg F. Bardenfleth (1871-1949); H. I. Boisen søn af skoleforstander, cand. theol. Peter Outzen Boisen (1815-1862) og hustru Meta Cathrine Marie Bang f. Grundtvig (1827-1887), Gr.'s datter. - ${ }^{6}$ ) Breve II: nr. 475, tidligst skrevet 28/4 og senest $4 / 5 .-{ }^{7}$ ) 1842 var Caroline Amalies for egne midler oprettede asyl flyttet til St. Kongensgade. I tilknytning til asylet oprettedes 1841 en skole, for hvilken Grundtvig var direktør, og P. O. Boisen (note 5) forstander 1851-1862. (Dronning Karoline Amalie (nærmest efter hendes egne breve) af H. Rosendal (Kbh. 1915)).$-^{8}$ ) Bibliografi II, nr. 746. $-^{9}$ ) brevet tidligere citeret bl. a. i Rønning IV, 1, s. 34. (I Danskeren V, s. 195 er dette brev ved (tryk)fejl dateret $3 / 5$; i et nu forsvundet brev fra Gr. til Gunni Busck fra april (?) 1843 (omtalt: Gr. til G. B. 6/5 1843 (note 12)) har Gr. fremsat ønske om at komme til England, og udelukket er det ikke, at dette ønske er videre befordret til dronningen. $-{ }^{10}$ ) Danskeren V, s. 195 bringer citater af ellers ukendt takkebrev fra Gr. til C. A. dateret $\% / 5$, og fra samme dag C. A. til Gr. med indbydelse til middagen d. $10 / 5$ på Sorgenfri (fasc. 450 ). - ${ }^{11}$ ) C. A. til Gr. $9 / 5$ (note 10). - ${ }^{12}$ ) Gr. til G. B. ${ }^{8 / 5}$ (Gunni Busck, et Levnedsløb i en Præstegaard. Udgivet af Henr. Bech. 2. udg. (Kbh. 1878), s. 275 f.) ; Gr. omtaler også den forestående rejse til bl. a. U. E. Hagerup, V. Birkedal (Breve II, nr. 471 og 472), B. S. Ingemann (Grundtvig og Ingemann. Brevvexling 1821-1859, udgiven og indledet af Svend Grundtvig (Kbh. 1882), nr. 107) og til P. Fenger (note 13). - ${ }^{13}$ ) Gr. til P. Fenger ${ }^{6 / 5}$ 1843: »Denne Reise betragter jeg som min lille Deel i »Missjonen«, Gud lade den lykkes til Herrens Ere og Hans Menigheds Gavn« (Breve II, nr. 473). - ${ }^{14}$ ) Gr. til C. A. $9 / 5$ (note 10). ${ }^{15}$ ) Grundtvig og England. Studier over Grundtvig af J. P. Bang (Kbh. 1932), s. 85 ff.; Kirkehistoriske Samlinger, 6. Rk., VI Bd. (Kbh. 1948-50), s. 272-83: Grundtvig og Puseys Oxforderbevægelse. Af Helge Toldberg; N. F. S. Grundtvig. An Introduction by P. G. Lindhardt (London 1951, s. 64-75. ${ }^{18}$ ) ${ }^{13} / 5$ kvitterer Gr. overfor kabinetssekretær J. G. Adler for »Creditivet, hvormed Hds. M. Dronningen med saa megen Naade vil forebygge muelig Forlegenhed «, og udbeder sig samtidig introduktion til den danske gesandt i London (note 79). Ligeledes udvirker han bl. a. et engelsk laissé passé (note 31) 
og træffer endelig dispositioner ang. »den lille Psalmebog « (den ikke udgivne samling: Psalme-Blade til Kirke-Bod) (Breve II, nr. 474 og Bibliografi II, nr. 745). - ${ }^{17}$ ) Nugent Wade (1809-1893), præst, traf som engl. konsultatspræst i Helsingør 1833-39 Gr., som tilegnede: „Aabent Vennebrev til en Engelsk Præst « til Wade, da denne i 1839 forlod Danmark for at tiltræede som kapellan ved St. Pauls, Finsbury. 1836 gift med Louisa Fenwick (f. 1817), datter af engl. generalkonsul Charles Fenwick (1775-1832) og hustru Susanna Johanne f. Berner (1788-1871). (Grundtvig-Studier 1948 (Kbh. 1948), s. 42-56: Nugent Wade i Helsingør. Af Helge Toldberg; Bibliografien II, nr. 626 A; Lensbaron Hans Berner Schilden Holsteins Slægtsbog, udarbejdet af Hans Berner Schilden Holstein og Albert Fabritius, I Del, 1 (Kbh. 1940-41), s. 261 og 264). $-{ }^{18}$ ) N. Wade til Gr. ${ }^{18 / 5}$ (fasc. 448; citeret i dansk oversættelse: Rønning IV, 1, s. 35). - ${ }^{10}$ ) Gr. prædikede ved både højmesse og aftensang såvel 1. som 2. pinsedag (Berl. Tid. ${ }^{3 / 6}$ ).

Brev 1: Halveret dobbeltark $(223 \times 270 \mathrm{~mm}$, sml. brev 3). Dobbeltfoldet på langs og tværs, sammenlimning præget med Gr.'s signet (afbildet.: Englandsbreve (note 1), s. XVI). Forsynet med udskrift på arkets bagside. - ${ }^{20}$ ) Dampskibet »Malmø« afsejlede ifl. ord. plan fra Kbh. onsdag d. ${ }^{7 / 6}, \mathrm{kl}$. 14 og ankom til Lübeck torsdag d. ${ }^{8 / 8}, \mathrm{kl} .12,30$ (Berl. Tid. ${ }^{28 / 5}$ og Rejse-Dagbog). - ${ }^{21}$ ) Hamb [org], overstreget og ændret til: Danmark. - ${ }^{22}$ ) Svenn Hersleb Grundtvig (1824-1883), litteraturforsker og folklorist, skulle følge og bistå Gr. på rejsen og selv i England og Skotland indsamle materiale til de afsluttende hefter af bogen: Engelske og Skotske Folkeviser, fordanskede af Svenn Grundtvig (Kbh. 1846). - ${ }^{23}$ ) Peter Frederich Quaade (1779-1850), generalmajor. - ${ }^{24}$ ) Frederik Lønborg (1790-1860), oberstløjtnans (Personalhistorisk Tidskrift 5. rk., IV bd. (Kbh. 1907), s. 51-85 og 166-78: Slægten Lønborg ved E. Marquard (se s. 174)). $-{ }^{25}$ ) passagerer på $\gg$ Malmø《 $7 / 6-8 / 6$ var: 》Generalmajor P. F. v. Quaade med Tjener og Eqvipage, Oberstltn. F. v. Lønborg, Pastor N. F. S. Grundtvig med Søn, Kbmd. F. Garriquez, I. Dumock og A. Hoeckt, Cancellist F. H. Dose, Partikulier F. Metzkus, Garver J. Levysohn, 4 Haandværkssvende (Berl. Tid. 8/8). Til ingen af de her opregnede personer synes dette ellers ukendte udtryk at kunne knyttes og må da rimeligvis forklares som Gr.'s danisering af titlen: jourhavende kaptajn, hvilken på »Malmø« indehavdes af svenskeren $\mathrm{O}$. Mattsson, der måske har foranlediget Gr.'s udtryk ved selv at have benyttet den sv. form: dagshavande i st. f. jourhavande (Ordbok över svenska språket utgiven av Svenska Akademien, VI og XIII (Lund 1925 og 1932). ${ }^{26}$ ) rejsen fortsattes fra Lübeck $\% / 6, \mathrm{kl}$. 6 med diligence, som ankom til Hamborg kl. 12,45 (Rejse-Dagbogen). - ${ }^{27}$ ) i uafsluttet og ikke afsendt brev til broderen Johan (note 29) skriver Sv. Gr.i London 15/6: »Strax ved Dampskibet blev vi prajet af »der Hausknecht« fra »fümf Thürmen«, det Gæstgiversted som Bojesener [ne] havde anbefalet os. Det hører til de simplere og vi fandt os ikke videre tilfredsstillede, hvad $\mathrm{Du}$ imidlertid ikke behøver at fortælle dem « (N.K.S.). $-{ }^{28}$ ) ifl. brev fra London ${ }^{25 / 8}$ sendte Sv. Gr. brev til Jh. Gr. fra Lübeck (»hvortil du i mit første brev fulgde mig«) (Gad XXV, s. 312). $\left.{ }^{29}\right)$ den ældste søn, Johan Diderik Nicolai Blicher Gr. (1822-1907), historiker og arkivar, og datteren Meta Gr. (note 5). - ${ }^{30}$ ) Jane Mathia Blicher (17911853), Lise Gr.'s yngste og ugifte søster, som i mange år havde sit hjem hos Gr. (Den falsterske Gejstligheds Personalhistorie. Ved Immanuel Barfod, II del (Nykøbing F. 1854), s. 85). 
Brev 2: Dobbeltark $(116 \times 181 \mathrm{~mm})$. I øverste hjørne til venstre er s. 1 præget med kronet: superfine note. Dobbeltfoldet på langs, lukket med rødt laksegl præget med lille signet, lady Rodstocks (?)) og forsynet med udskrift på side 4. - ${ }^{31}$ ) Catherine E. Puget (datter af direktør ved Bank of England, John P. of Totterigde) g. m. Peter Browne (1794-1872), der som chargé d'affaires ved det engl. gesandtskab i Kbh. (i flere perioder $i$ årene 1824 til 1857) kom $\mathrm{i}$ venskabelig forbindelse med Gr. og udstedte $7 / 61843$ et laissé passé for Gr. til brug på englandsrejsen (fasc. 516). 1841-55 ejede P. B. landstedet 》Rolighed《 mellem Skodsborg og Vedbæk. P. B.'s søn: Peter Dennis Browne var nær ven med Jh. og Sv. Gr. (M.E. B. I og Eiler Nystrøm: Fra Nordsjællands Øresundskyst, Gentofte, Lyngby og Søllerød Sogne i Fortid og Nutid (Kbh. 1938), s. $379 \mathrm{ff}$ ). - ${ }^{32}$ ) senere tilføjet i marginen. ${ }^{33}$ ) Esther Caroline Puget (faderen, se note 31) g. m. George Granville Waldegrave, 2nd Baron of Radstock (1786-1857), Viceadmiral (Burke's genealogical and heraldic history of the Peerage, Barontage and Knightage (London 1949)). $-{ }^{34}$ ) i brev (i Ingolf Boisens arkiv) til moderen afsendt: »Hamborg. Fredag, $8 / 6$ 43« meddeler Sv. Gr. ankomsten til Hamburg, hvor Gr. tog ind på hotel (Hamburgischer Correspondent, 12/8: »Angekommene Fremde, Hotel de France: Die HH. Gramtwig, Prediger nebst Sohn, v. Kopenhagen «), indtil de efter kort tur i byen kl. 20,30 gik om bord i det engl. dampskib 》Caledonia«, som over midnat afsejlede direkte til London (Hamburgischer Correspondent, ${ }^{10} \%$ og Rejse-Dagbog). - ${ }^{35}$ ) se note 31.

Brev 3: Dobbeltark $(223 \times 270 \mathrm{~mm})$. Tilsvarende ark anvendt som kuvert (omslag), lukket med rødt laksegl (præget med Gr.'s signet) og forsynet med udskrift. - ${ }^{36}$ ) Sv. Gr. til Jh. Gr. 15/6 (note 27): »Fader var langt raskere [end Sv. Gr.] og gik af og til op på Dækket og røg sin Pibe, hvorfor Kaptajnen sagde til ham at han var 》the most comfortable man on board« (for han var den eneste der kunde tage sig det for) «. - ${ }^{37}$ ) RejseDagbogen, ${ }^{13} / 6$ : $\gg I$ Formiddags var Fader på British Museum, traf ingen af sine gamle Bekjendte uden Inspektøren på Læsesalen. Han efterlod da et Brev til Sekretæren Mr. J. Forshall, hvori han begærede Adgang for sig og mig. Endnu samme Aften ankom Tilladelsen«. Sst., 14/6: 》Var jeg for første Gang i det britiske Museums Læsesal og skrev mit Navn i dens Bog«. Sst., ${ }^{16 / 6}$ : 》Idag begyndte jeg mit Arbejde på British Museum«. - ${ }^{38}$ ) Edward Bouverie Pusey (1800-1882), professor i hebraisk, tilsluttede sig 1835 oxfordbevægelsen og blev dennes egentlige leder, da Newmann (note 57) konverterede; Gr. købte i 1843 Pusey's »Letter to the Archbishop of Canterbury« 3d Ed. (Oxford 1842) og 》Sermon before the University ( (London 1843). (Catalouge). - ${ }^{30}$ ) $\mathrm{i}$ sit brev til Caroline Amalie ${ }^{13 /{ }^{6}-15 / 6}$ (Danskeren V, nr. 1) bringer Gr. en ret udførlig omtale af dette møde i Overhuset, hvor det »ved et godt Lykketræf « var en kirkepolitisk sag (den skotske frikirke-bevægelse), som var til behandling. $-{ }^{40}$ ) Arthur Wellesley, 1st duke of Wellington (1769-1852), general og fremtrædende politiker (tory). - ${ }^{41}$ ) George Hamilton-Gordon, 4th earl of Aberdeen (1784-1860), politiker (tory) og flere gange udenrigsminister (sidst 1841-46). - ${ }^{42}$ ) Henry Peter Brougham, 1st baron of Brougham and Vaux (1778-1868), advokat og politiker (liberal), kendt bl. a. som forkæmper for slaveriets ophævelse; Gr. omtaler ikke Br. i brevet til C. A. 13/6 - 15/6 (note 39). - ${ }^{43}$ ) Jens Andersen Schouborg (f. ca. 1759), degn i Levring og Hørup (1802) og sønnen Anders Jensen Schouborg (døbt 15/1, 1786 i Linnerup) (Danskeren V, nr. 1; Hamburgischer Correspondent; Lands- 
arkivet for Nørrejylland, Viborg). - ${ }^{44}$ ) Gr. henviser her til brevet til C. A., som er angivet påbegyndt ${ }^{13} / 6$ og afsluttet $15 / 6$ (note 39). - ${ }^{45}$ ) P. O. Boisen (note 5) og broderen Otto Harald Benedictus Boisen (1817-1894), som begge var ansat ved dronningens asyl og skole (note 7). - ${ }^{46}$ ) Rasmus Theodor Fenger (1816-1889), præst, bistod Gr. ved arbejdet med salmebogen: »Psalme-Blade til Kirke-Bod« (note 16). - ${ }^{47}$ ) Gr. skrev samme dag til Jh. Gr. ang. dennes fremtidsplaner (Breve II, nr. 477). Gr.breve til Meta Gr. er ukendt fra denne rejse. - ${ }^{48}$ ) Gunni Busck (1798-1869), præst og Gr.'s nære ven, havde i brev $18 / 5$ fortalt Gr., at han med sine børn ville tilbringe 14 dage af juni på familiens lille landsted »Strandlyst《 $i$ Vedbæk $(H$. Beck: Gunni Busck (note 12), s. 284, og Minder fra gamle grundtvigske Hjem, samlede af Dr. H. P. B. Barfod (Kbh. 1921), s. 51-60: Minder fra Præsten Gunni Buscks Hjem. Af Fru Aug. Pedersen, f. Busck (se s. 59)). - ${ }^{49}$ ) Bodil Marie Elisabeth Blicher (1783-1862) g. m. Poul Egede Glahn (1778-1846), residerende kapellan ved Garnisons Kirke i Kbh., og Anne Povline Blicher (1785-1880) g. m. Kristian August Schmidt (1770-1853), grosserer (Barfod, note 30$).-{ }^{50}$ ) se note 49 .

Brev 4: 2 ulige store dobbeltark $(167 \times 202 \mathrm{~mm}$ og $223 \times 270 \mathrm{~mm})$. Kuvert $(125 \times 76 \mathrm{~mm})$ med klap lukket med grøn papiroblat. $\left.-{ }^{51}\right)$ tilføjet senere, da brevets afslutning er trukket ud. - ${ }^{52}$ ) Lise og Meta Gr.'s breve er ikke kendte, men derimod Sv. Gr.'s følgebrev $28 / 6$ ved fremsendelsen af brevene. (Gad XXV, s. 410 f.) - ${ }^{53}$ ) Gr. opgiver i brev til Sv. Gr. sin adresse til High Street nr. 50 og boede ikke på »Queens College«, som bl. a. Rønning (IV 1, s. 37) oplyser. (Gad XXV, s. 410) - ${ }^{54}$ ) 》Queens College《 (oprettet 1340), som »var mig for Navnets Skyld dobbelt kjært« (Gr. til Caroline Amalie, 2/8 (Danskeren V, nr. 2)), lå i umiddelbar nærhed af Gr.'s logi. - ${ }^{55}$ ) John Barrow (1810-1881), tutor og bibliotekar ved »Queens Coll.« 1835-1846, konverterede 1864; forærede Gr. »Ten Parts of Tracts for the Times« (hvilke, er ikke angivet). (M. E. B. IV og Cataloque). - ${ }^{58}$ ) Charles Daman (f. 1813), fellow v. »Oriel coll.« 1836-42. (Oxford Men \& Their Colleges by Joseph Foster (Oxford 1893), spl. 152). - ${ }^{57}$ ) John Henry Newman $(1801-1890)$, teolog og vicepræst v. Sct. Mary (Oxford) og annekset Littlemore. Udgav selv 1833 den første og redigerede siden de følgende $\gg T$ Tracts for the Times by Members of the University of Oxford«, hvori samledes en række af oxfordbevægelsens væsentligste kampskrifter (note 55). I febr. 1843 tilbagekaldte Newman alle sine tidligere angreb på romerkirken, hvortil han 1845 konverterede. Gr. købte 1843: 》Selection from Dr. Newmans Sermons (London 1841). (Catalogue). 59) 》Oriel coll.« (oprettet 1326) regnedes blandt Oxfords fornemste coll. og var et af centrene for oxfordbevægelsen. - ${ }^{59}$ ) Samuel Waldegrave (18171869), valgt fellow ved 》All Souls coll.« 1839-45. 1860 biskop i Carlisle. (D. N. B. LIX) . - ${ }^{60}$ ) utydeligt skrevet: Uge, overstreget og tydeligere gentaget: Uge. - ${ }^{61}$ ) rettet fra: havd. - ${ }^{62}$ ) Edward Arthur Litton (18131897), fellow ved 》Oriel coll.« 1836-43. Sognepræst i Naunton, 1860-97. (M.E.B. VI) . - ${ }^{83}$ ) Edward Meyrick Goulburne (1818-1897), fellow ved »Merton coll.« $1841-45$ og tutor og dean sst. 1843-45. (M.E. B. V). $\left.{ }^{64}\right)$ det afsluttende citationstegn utydeligt her, måske udeladt efter: »Daaben«. - ${ }^{85}$ ) Rejse-Dagbog, ${ }^{27 / 6}$ : 》ved Frokostbordet bekjendtgjorde Mrs. Wade et brev fra Fader der indbød mig til Oxford «. - ${ }^{86}$ ) noget møde omtaltes ikke af Gr., og er næppe kommet istand. $-{ }^{67}$ ) rettet fra: Vice-Cancelleren. $-{ }^{68}$ ) og, overstreget og ændret til: eller. - ${ }^{69}$ ) Henry Booth by Barry (senere fellow ved »Queens coll.«) modtog 1843 »The Chancellor's Price《 $\mathrm{i}$ disciplinen »Eng- 
lish essay « for en prisopgave med titlen: 》The Advantages and Disadvantages of the Feudal System «. (The Historical Register of The University of Oxford (Oxford 1888), s. 142); Brun (I, s. 184), som omtaler Gr.'s tale ved selskabet for Barry, lader fejlagtigt forstå, at denne blev holdt ved selve universitetsfesten. - ${ }^{70}$ ) til ingen af de to her næunte forelæsninger kendes opskrifter fra Gr's hånd. - ${ }^{71}$ ) Sir John Bowring (1792-1872), sprogforsker, forfatter og politiker, var 1829 i Danmark, hvor han bl. a. traf Gr., som på sine rejser til England i 1830 og 1831 besøgte B. (D. N.B. VI). - ${ }^{72}$ ) fejlskrivning for: Juli. - ${ }^{73}$ ) herfra og afsnittet ud skrevet i venstre margin på brevets s. 8. ${ }^{74}$ ) herfra og brevet ud skrevet i venstre margin på brevets s. 6. - ${ }^{75}$ ) udskriften så kort, da Dennis Browne skulle bringe brevet til Lise Gr. i Kbh. (note 86).

Brev 5: Dobbeltark $(114 \times 190 \mathrm{~mm}$, vandmærke: J. Whatman 1842, sml. brev 6). Kuvert $(125 \times 76 \mathrm{~mm})$ med klap, lukket med rødt laksegl (præget med Gr.'s signet). - ${ }^{76}$ ) Lise Gr.'s bror Hans Jakob Blicher (1789-1863) var overlærer i Nykjøbing F. - ${ }^{77}$ ) i brev til Caroline Amalie ${ }^{26 / 6}$ (Gad XXV, nr. 3) omtaler Gr. sine egne studier på British Museum. Ifl. Sir Frederich Madden's dagbog (Orbis litterarum, IV (Kbh. 1947), s. 258-311: Grundtvig og de engelske antikvarer af Helge Toldberg (se s. 307)) besøgte Gr. denne to gange d. $1 / 7$ og $7 / 7$, hvortil må føjes $5 / 7$, da Gr. forestillede Sv. Gr. for håndskriftsafdelingens leder (Rejse-Dagbog). $-{ }^{78}$ ) Catalogue - som i forbindelse med Gr.'s bogsamling iøvrigt fortjener en nærmere analyse - giver en god forestilling om Gr.'s omfattende bogindkøb på rejsen (ialt for næsten $26 \mathfrak{f}$ ). Rejse-Dagbog, ${ }^{6} / 7$ : »gik vi [Gr. og Sv. Gr.] hen til Boghandleren [W.] Pickering hvor vi tilbragte næsten 2 Timer imellem alle hans Bøger «. - ${ }^{78}$ ) Frederik Detlef Greve Reventlow (1791-1851), udnæunt til dansk gesandt i London 1841 , sendte med brev ${ }^{17} / 7 \mathrm{Gr}$. en introduktionsskrivelse til biskoppen af Peterborough, hvem Gr. dog ikke besøgte. Hvem af gesandtens mange søskende Gr. traf ved besøget er usikkert. - ${ }^{80}$ ) Richard Whately (1787-1863), fra 1831 xrkebiskop af Dublin (D. N. B., LX). $-{ }^{81}$ ) besøget $i$ 》The Chinese Collection « fandt sted $8 / 7$ (Rejse-Dagbog), og Gr. købte: Descriptive Catalogue of the Chinese Collection, now exhibiting at St. Georg's Place, Hyde Park Corner; By William B. Langdon, Esq. (London 1843). (Catalogue). - ${ }^{82}$ ) Reform Club House, som 1837-40 var bygget af arkitekten Sir Charles Barry med Palazzo Farnese som forbillede, har tydeligt nok imponeret Gr. langt mere end litteraternes klubhus, Athenæum Club (opført af Decimus Burton 1829-30), som mr. Bowring også fremviste efter frokosten $4 / 7$, hvortil han havde indbudt Gr. og Sv. Gr. i et ret formelt brev, 3/6 (Rejse-Dagbog og fasc. 448).

Brev 6: Dobbeltark $(190 \times 228$, vandmærke: J. Whatman 1842). Kuvert (omslag) af tykt papir, lukket med grønt laksegl (ingen prægning af signet). - ${ }^{83}$ ) også overfor Caroline Amalie giver Gr. udtryk for skuffelse over dette besøg i Underhuset (Danskeren V, nr. 3), hvorom Sv. Gr. skriver: »Robert Peel så jeg kun, men Lord Russel hørte jeg også«. (Rejse-Dagbog). - ${ }^{84}$ ) Sir Robert Harry Inglis (1786-1855), politiker, som varm tilhænger af den anglikanske nationalkirke-tanke var han blandt de ivrigste modstandere mod den ligestilling af katolikerne, som fandt sted i slutningen af 1820erne. - ${ }^{85}$ ) barnet som var født $1 / 6$ (brev 4) fik navnet: Louisa Anne Wade (Lensbaron Hans Berner Schilden Holstein's Slægtebog (note 17), s. 266). - ${ }^{88}$ ) i brev til Gr. afsendt: »Rolighed, Monday July 10th« beder Dennis Browne Gr. undskylde, 
at hans rejsepult, indeholdende bl. a. Gr.'s breve til hjemmet og til Caroline Amalie, (som han troede) var stjålet fra ham på skibet. (fasc. 465). - ${ }^{87}$ ) Søndag d. $23 / 7$ havde Gr. og Sv. Gr. "Næesen indenfor Døren af det romerskkatolske Kapel« og var samme dags aften i Wesley's Chapel (»Cathedral of Methodism«, som Gr. over Artillery Ground's »Grønning« (sml. brev 9) kunne se fra sine vinduer i Bunwill Row) og hørte »en overordentlig god Prædiken «, hvilken han siden mindes, når han siger: »Da jeg tænkte: i Guds Time / Her endnu vil Klokker kime / Engle kvæde højt i Sky!«. (Rejse-Dagbog. Danskeren V, nr. 6 og Christenhedens Syvstjerne. Et Kirkeligt Sagakvad af N. F. S. Grundtvig (Kbh. 1860), s. 106 (Biografi III, nr. 1121)). - ${ }^{88}$ ) Christian Jürgensen Thomsen (1788-1865), arkæolog og senere direktør for »Oldnordisk Museum «. - ${ }^{89}$ ) Hans Paludan Smith Schreuder (1817-1882), norsk missionær, var ${ }^{16 / 7}$ kommet til London for derfra at rejse til Sydafrika, hvor han grundlagde missionen bl. Zulufolkene (Brun I, s. $185 \mathrm{f}$, A. Olsen: Missionsbiskop H. P. S. Schreuder, hans Liv og Virke (Kbh. 1917), s. 14 og RejseDagbog)). - ${ }^{80}$ ) til Gunni Busck i Stigs Bjærgby. - ${ }^{81}$ ) Breve II, nr. 478. ${ }^{82}$ ) herfra og ud er brevet skrevet i venstre margin på brevets s. 4. - ${ }^{\text {93 }}$ ) Udskriften ikke af Gr., måske først skrevet efter at brevet er bragt til Kbh. af Susanne Fenwick (note 17).

Brev 7: Dobbeltark $(187 \times 233 \mathrm{~mm})$ på øverste halvdel er s. 1 forsynet med litograferet prospekt af High Street i Oxford. Kuvert $(126 \times 77 \mathrm{~mm}) \mathrm{med}$ klap, lukket med rødt laksegl, (præget med utydeligt signet, ikke Gr.'s). ${ }^{84)}$ Mandag d. ${ }^{24} / 6$ rejste Gr., Wade og Sv. Gr. kl. 11 fra London og ankom kl. 18 til Oxford. (Rejse-Dagbog). - ${ }^{85}$ ) se afbildningen s. . . ${ }^{86}$ ) senere tilføjet over linien. - ${ }^{97}$ ) formodentlig til W. Palmer (note 109), som ${ }^{25} / 8$ takker Gr., fordi »You sent me a letter when You were on the point of leaving Oxford«, og fra hvem endvidere kendes endnu et brev 3/8. (facs. 448). -

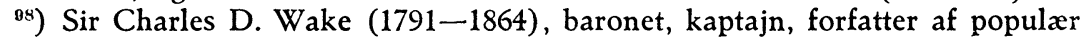
kommentar til NT, havde af Dennis Browne hørt, at Gr. var i England, og skrev allerede $26 / 6$ og bad $\mathrm{Gr}$. besøge sig, gentager dette $13 / 7$ og beklager $3 / 8$, at Gr. ikke kommer (M.E. B., VI og fasc. 448). - ${ }^{89}$ ) »All Souls coll.« (oprettet 1438) har aldrig optaget »undergraduates«, men alene været forbeholdt universitetets professorer og særlig fremragende lærde. - ${ }^{100}$ ) Til $\gg$ Magdalen coll.« (oprettet 1458), som Gr. under dette Oxford-ophold mest besøgte (Gad XXV, nr. 4), hører Oxfords vartegn, det 145 fod høje klokketaarn, hvis karakteristiske arkitektur Gr. utvivlsomt har haft i tanken, da han skrev: »Eller tegne vel til Spire / Spydene i Hjørner fire / Paa dit platte Kirketaarn?« /. (Christenhedens Syvstjerne (note 87), s. 104). - 101) Martin Joseph Routh (1755-1854), fra 1791 president for »Magdalen coll.« (D. N. B. XLIX). $\left.{ }^{102}\right)$ The Bodleian Library, oprettet 1602 af Sir Thomas Bodley. - ${ }^{103}$ ) Bulkeley Bandinel (1781-1861), bibliotekar, overbibliotekar v. Bodleian Library 181360. (D. N.B. III). - ${ }^{104}$ ) Refererer formodentlig til tildragelse på Sv. Gr.'s fodtur 1842, hvorfra er bevaret fragmentariske optegnelser (D. F. S.). - ${ }^{105}$ ) I 》Trinity coll.« (oprettet 1554) findes den kostbare middelalderlige sølv-kalk og -disk, som skænkedes coll. af grundlæggeren Sir Thomas Pope. (Oxford, s. 217). - ${ }^{106}$ ) Såvel »University coll.« som »Balliol coll.« (oprettet henholdsvis 1249 og 1263) er aldre end »Merton coll.« (oprettet 1264), ved hvilken imidlertid dannedes det første samlede og endnu bevarede kollegiekompleks, den berømte »Mob Quad« (1308-78) (Oxford, University and City by A. R. Wolley, M. A. (London 1951), s. 24 og 86-87). - ${ }^{107}$ ) Den oprindelige sogne- 
kirke (indviet til Johannes Døberen) er, som ante-kapel, sammenbygget med 》Merton College Chapel« (Oxford, s. 55). - ${ }^{108}$ ) I dag Englands æaldste bevarede bibliotek (Wolley (note 106), s. 101). - 109) William Palmer (18111879), fellow v. 》Magdalen coll.«, studerede 1840-41 i Rusland, nærmede sig en overgang den grask-katolske kirke, konverterede 1855 og døde i Rom. (Bibliographical Dictionary of the English Catholics. By Joseph Gillow, V (London 1885)).

Brev 8: Dobbeltark $(113 \times 185 \mathrm{~mm}$, sml. brev 9$)$. Kuvert $(120 \times 71)$ med klap, lukket med blå papiroblat med gult: G. $-{ }^{110}$ ) opholdet i Edinburgh varede således fra søndag d. $6 / 8$ til torsdag d. $10 / 8$. - ${ }^{111}$ ) Gr. beså bl. a. domkirken (St. Giles), slottet og Knox hus samt overværede en gudstjeneste på åben gade (Rejse-Dagbog, 6/8). - ${ }^{112}$ ) David Laing (1793-1878), bibliotekar 1837 ved »Signet Library《 (D. N. B. XXXI); fra F. Madden (note 77) havde Gr. introdukionsskrivelse til Laing. (Rejse-Dagbog, $7 / 8$ ). - 113) Thomas Chalmers (1780-1847), professor i theologi ved Edinburgh Univ. 1828, leder den nationalt betonede vakkelse, som førte til konstitutionen af »The free Church of Scotland« $18 / 5$ 1843. (D. N. B. IX). - ${ }^{114}$ ) foruden det tidligere (note 34) næunte brev kendes kun to rejsebreve (alle i I. Boisens arkiv) fra Sv. Gr. til Lise Gr.: »London, Mandag d. 26de Juni 43《 og »Edinburg, Søndag d. 7de Aug. $1845 \ll$, til hvilket sidste, som iøvrigt kun bringer sønnens lykønskning i anledning af sølvbrylluppet (note 116), er føjet et efterskrift dateret: »Edinburg Onsdag d. 10de๔. Den bedste, kendte kilde til fastlæggelse af rejsen til Skotland er da Sv. Gr.'s Rejse-Dagbog, fra hvilken rejseruten kan sammenfattes således: ${ }^{31} / 7$, fra Oxford over Stratford til Birmingham (med diligence); $1 / 8$, fra Birmingham (med toget) via Manchester (kort besøg i domkirken) til Lancaster, derfra ad Lancaster-Kendal-kanalen til Kendal; $2 / 8$, ophold hos mr. Barrow (note 55) i Kendal (udflugter i omegnen); $3 / 8$, fra Kendal over Bowness og langs bredden af Windermere til Ambleside, hvorfra fortsattes til Keswick ved Derwent Water (her rotur om aftenen); $4 / 8$, fra Keswick til Penrith (besøg i kirken og "på kirkegården med Jxttegravene«), herfra med diligence til Carlisle; $5 / 8$, da der ikke var plads i postvognen til Glasgow, fortsattes med diligencen over Abbotsford til Edinburgh (ankomst kl. 3 nat efter 10 timers rejse). - ${ }^{115}$ ) 18/6 sendte P. Rørdam (note 125) gennem P. Browne (note 31) et langt brev til Gr. (Peter Rørdam. Blade af hans Levnedsbog og Brevvexling fra 1806 til 1844 af H. F. Rørdam (Kbh. 1891), s. $291 \mathrm{ff}$.). $\left.{ }^{116}\right)$ Gr. og Lise Blicher blev gift ${ }^{12} / 81818$ (note 132). - ${ }^{117}$ ) Gr. har tilsyneladende sendt sine breve til familien Browne i London og derfra gennem gesandtskabet fået det befordret til Kbh.

Brev 9: Dobbeltark $(185 \times 226 \mathrm{~mm}$, i øverste venstre hjørne er s. 1 præget med krone). Kuvert $(126 \times 77 \mathrm{~mm})$ med klap, lukket med rødt laksegl (præget med Gr.'s signet). - ${ }^{118}$ ) nu ulæseligt, længere ord rettet til: færre. - $\left.{ }^{119}\right)$ i »Advocates library« i Edinburgh, som Gr. og Sv. Gr. også besøgte. (RejseDagbog, ${ }^{9 / 8}$ og D. N. B. XXIX). $-{ }^{120}$ ) aftenvandring i ruinerne af cistercienser abbediet (grundlagt 1136) i Melrose omtaler Gr. i: Kirke-Speil eller Udsigt over den christne Menigheds Levnetsløb. Efter mundtlig foredrag 1861-63 af Nik. Fred. Sev. Grundtvig, Præst ved Vartou (Kbh. 1871), s. 180 (Bibliografi III, nr. $1461 \mathrm{~A}$ ). - ${ }^{121}$ ) Gr. til Caroline Amalie, 18/8: Vel gjorde Digteren Southeys Hus mellem Cumberlands Bjærge, som stod øde og var tilleje, mere Indtryk paa mig end Herregaarden ved Tved«, men Walter Scott's (1771- 
1832) gamle slidte Lænestol »den vakte dog min Skriver-Sympati«. (Danskeren V, nr. 5). - ${ }^{122}$ ) en, rettet til: et. - ${ }^{123}$ ) James Raine (1791-1858) bibliotekar, 1816-58 i Durham (D. N. B. XLVII). - ${ }^{124}$ ) Walther Farquhar Hook (1798-1875), præst, virkede kraftigt iblandt den store industribefolkning og sympatiserede med oxforderne, men bør ikke, som Gr. gør det, henregnes blandt bevægelsens ledere (D. N. B. XXVII); hos Hook traf Gr. S. T. Coleridges ene søn, forfatteren Hartley C. (1796-1849), og ${ }^{22} / 8$ besøger Gr. og Sv. Gr. en anden søn, pædagogen Derwent C. (1800-1883), leder af St. Mark's coll., Chelsea 1841-64 (Rejse-Dagbog og D. N. B. XI). - ${ }^{125}$ ) Gr. formoder (sml. brev 8), at Lise Gr. med de to børn er hos vennen P. Rørdam (18061883); var fra 1841-56 sognepræst i Mern. - ${ }^{126}$ ) Opmærksomheden, ved overstregning rettet til: Opmærksomhed. $-{ }^{127}$ ) Jh. Gr. skriver fra »Nykjøbing F. 6. Aug. 1843 « til Sv. Gr. og meddeler, at han opholder sig hos morbroderen: Hans Jacob Blicher (1789-1863), overlærer i Nykøbing F. (N.K.S. og Barfod (note 30)). $-{ }^{128}$ ) senere tilføjet over linien. $-{ }^{129}$ ) se note 49.

Brev 10: Dobbeltark $(185 \times 226 \mathrm{~mm}$, i øverste venstre hjørne er s. 1 præget med krone). Kuvert $(126 \times 77 \mathrm{~mm})$ med klap, lukket med rødt laksegl (præget med Gr.'s signet). - ${ }^{130}$ ) St. Pauls Cathedral opført 1675-1710 med Sir Christopher Wren som arkitekt. - ${ }^{131}$ ) senere tilføjet over linien. ${ }^{132}$ ) i sit forsinkede sølvbryllupsdigt på bryllupsdagen 1844 »Til min Lise《 nævner Gr. atter dette: »Let fløj dit Brev over Hav, / Vi mødtes paa DagvognsSædet«; (Bibliografi II, nr. 786). - ${ }^{133}$ ) oss [elv], rettet ved overstregning til: os. - ${ }^{134}$ ) og, overstreget og ændret til: saa. - ${ }^{135}$ ) s[aa], overstreget og ændret til: jeg.

Brev 11: Dobbeltark $(113 \times 185 \mathrm{~mm}$, sml. brev 8 og 9 , i øverste højre hjørne er $\mathrm{s} .3$ præget med krone). Kuvert $(119 \times 71 \mathrm{~mm})$ med klap, lukket med rødt laksegl (præget med Gr.'s signet). - ${ }^{136}$ ) Gr. skrev ikke hjem efter 28/8, og oplysninger, ang. hjemrejsen, må hentes i Rejse-Dagbog: 1/, kl. 14,30 fra London på engelsk dampskib »Neptun «; ${ }^{4 / 9}, \mathrm{kl}$. 11,00 i Hamborg, og derfra med diligencen kl. 19,00; 5/9, kl. 5,00 i Kiel, hvor Gr. og Sv. Gr. besøgte professor Chr. Flor og senere gik tur i byen; ${ }^{6 / 9}, \mathrm{kl}$. 14,00 ombord i dampskibet »Christian d. VIII«, (efter at have modtaget to breve fra hjemmet); 7/, kl. 9,00 ankomst til Kbh. - ${ }^{137}$ ) Sv. Gr., som forneden på siden har gjort denne anmærkning, har ikke i Gr.'s brev direkte markeret det sted, hvortil noten henviser. - ${ }^{138}$ ) Ebenezer Henderson (1784-1858), præst, stod bag oprettelsen af såvel det danske som svenske bibelselskab (1814), virkede $i$ Islandsmissionen, 1830-50 tutor ved Highbury College ved London. Henderson havde allerede 1816 hørt Gr. prædike og formodentlig dengang også talt med Gr. (ifl. Rejse-Dagbog fandt mødet sted »for 26 Aar siden « = 1817). (Thulia S. Henderson: Memoir of the Rev. E. Henderson, D. D., Ph. D. including his labours in Denmark, Iceland, Russia etc., etc. (London 1859), s. 185 og 399 ff.). - ${ }^{138}$ ) jeg, overstreget og æendret til: han. - ${ }^{140}$ ) Hampton Court Palace, efter ombygningen 1689-1700 (arkitekt Sir Christopher Wren) det største engelske kongeslot. - $\left.{ }^{141}\right)$ umiddelbart før afrejsen fra London $(1 / 9)$ modtog Gr. brev fra R. Th. Fenger (note 46), skrevet »Christianshavn d. 26. August 1843« (Rejse-Dagbog og fasc. 412). 